\title{
Petrography and mineral chemistry of carbonatites and mica-rich rocks from the Araxá complex (Alto Paranaíba Province, Brazil)
}

\author{
GIANBOSCO TRAVERSA ${ }^{1}$, CELSO B. GOMES ${ }^{2}$, PIERO BROTZU ${ }^{3}$, \\ NICOLETTA BURAGLINI ${ }^{4}$, LUCIO MORBIDELLI ${ }^{1}$, MARIA SPERANZA PRINCIPATO ${ }^{5}$, \\ SARA RONCA ${ }^{1}$ and EXCELSO RUBERTI ${ }^{2}$
}

\footnotetext{
${ }^{1}$ Dipartimento di Scienze della Terra, Università di Roma "La Sapienza", Piazzale Aldo Moro, I-00185 Roma, Italy

${ }^{2}$ Instituto de Geociências, Universidade de São Paulo, Rua do Lago 562, 05508-900 São Paulo, Brazil

${ }^{3}$ Dipartimento di Scienze della Terra, Università di Napoli, Largo S. Marcellino 10, I-80134 Napoli, Italy

${ }^{4}$ Dipartimento Scienze della Terra, Università di Catania, Corso d'Italia 55, I-95129, Catania, Italy

${ }^{5}$ Dipartimento Scienze della Terra, Università di Milano, Via Mangiagalli 34, I-20133 Milano, Italy
}

Manuscript received on October 25, 1999; accepted for publication on June 1, 2000;

contributed by CELSO DE BARros GOMEs*

\begin{abstract}
The Araxá complex $\left(16 \mathrm{~km}^{2}\right)$ comprises carbonatites forming a central core and a complex network of concentric and radial dykes as well as small veins; additionally, it includes mica-rich rocks, phoscorites and lamprophyres. Fenites also occur and are represented by Proterozoic quartzites and schists of the Araxá Group.

The petrographic study of 130 borehole samples indicates that the complex is basically made up by two rock-types, carbonatites and mica-rich rocks, and subordinately by a third unit of hybrid composition.

Carbonatites range chemically in composition, the most abundant type being magnesiocarbonatites. Dolomite and calcite correspond to the chief constituents, but other carbonate phases, including the Ce-group RE minerals, are also recognized. Phosphates and oxides are widespread accessories whereas silicate minerals consist of olivine, clinopyroxene, mica and amphibole.

Mica-rich rocks are represented by abundant glimmeritic rocks and scarce cumulitic phlogopite-, olivine- and diopside-bearing pyroxenites. Hybrid rocks mainly contain phlogopite and tetraferriphlogopite as cumulus and intercumulus phases, respectively; carbonate minerals may also be found.

Chemical data indicate that the carbonatites are strongly enriched in REE and have lower contents of $\mathrm{Nb}, \mathrm{Zr}$, $\mathrm{V}, \mathrm{Cr}, \mathrm{Ni}$ and $\mathrm{Rb}$ compared to the mica-rich rocks. The higher $\mathrm{K}, \mathrm{Nb}$ and $\mathrm{Zr}$ contents of the latter rocks are believed to be related to metasomatic processes (glimmeritization) of the pyroxenites.

Similar REE patterns for carbonatites and mica-rich rocks seem to suggest that they are related to a single parental magma, possibly of ijolitic composition. Steep LREE/HREE fractionation and high $\Sigma$ REE content of some carbonatite samples would be explained by hydrothermal and supergenic processes.
\end{abstract}

Key words: alkaline rocks, carbonatites, geochemistry.

\section{INTRODUCTION}

* Member of Academia Brasileira de Ciências Correspondence to: Celso de Barros Gomes E-mail: cgomes@usp.br
Alkaline rocks are found in southern Brazil in association with the Ordovician-Cretaceous sedimen- 
tary Paraná Basin and mainly distributed along its margins. They vary considerably in age (about 130 to $50 \mathrm{Ma}$, cf. Ulbrich \& Gomes 1981) and composition, and have been assembled into distinct geographic provinces, such as the Alto Paranaíba Igneous Province (APIP), representing one of their most important ones, particularly due to the presence of economical deposits bearing niobium, phosphate, titanium and rare earth elements.

The Alto Paranaíba Province, which includes the renowned carbonatite intrusion of Araxá covering approximately $16 \mathrm{~km}^{2}$, is in general related to a NW-trending linear structure bordering the São Francisco cratonic area (Fig. 1), which is thought to be in evidence since late Precambrian times. It comprises a large number of occurrences showing a wide variety of igneous forms and magma types. The emplacement of these numerous Mesozoic intrusions fits a narrow Proterozoic mobile belt of the Brasiliano Cycle (700-450 Ma, cf. Almeida et al. 1973), extending some $1500 \mathrm{~km}$ in central Brazil and also referred to as the Brasília folded belt. As pointed by geological and geophysical evidence (Hasui et al. 1975, Almeida et al. 1980, Pires 1986), the whole area corresponds to a well-defined regional high, the Alto Paranaíba arch, about $100 \mathrm{~km}$ wide and $300 \mathrm{~km}$ long.

This paper aims to discuss the petrography and geochemistry of the Araxá carbonatites and micarich rocks on the basis of data taken from drill-core samples. Considering the poor geology of the area, with the extensive and deep weathering forming lateritic soil mantles averaging $80 \mathrm{~m}$ thick and reaching $230 \mathrm{~m}$ in many places, the now available data represent a very important source of information that will certainly contribute to the better knowledge of these rocks.

\section{THE ARAXÁ COMPLEX}

Previously reported in literature as Barreiro, it consists of a circular intrusion, $4.5 \mathrm{~km}$ in diameter, with the central part mainly formed by a carbonatite predominantly beforsitic in composition (Fig. 2). A complex network of carbonatite as concentric and radial dykes quite variable in dimension and also small veins ranging from few milimeters to several centimeters in thickness are present intruding either alkaline or country-rocks. Additional lithologies include mica-rich rocks, phoscorites and lamprophyres. The complex has been emplaced into Proterozoic quartzites and schists of the Araxá Group and developed concentric and radial fractures and a very conspicuous dome structure within the country rocks. Also associated to these rocks (specially the quartzites) is the presence of up to $2.5 \mathrm{~km}$ wide contact aureole exhibiting clear textural, mineralogical and chemical evidence of fenitization processes (Issa Filho et al. 1984).

Radiometric ages on Araxá alkaline rocks were compiled for the first time by Ulbrich and Gomes (1981) and later on by Sonoki and Garda (1988), Gomes et al. (1990) and Morbidelli et al. (1995), with the whole data indicating an age span of 77-98 Ma. Also recently, Gibson et al. (1995) have discussed the age of magmatism in the Alto Paranaíba Province using values (old and new ones) obtained by different methods (K/Ar, Ar/Ar, U/Pb) on rocks and mineral separates from several occurrences, here included the Araxá complex. They concluded that the alkaline magmatic activity in the area had occurred over a narrow time interval between 80 and $90 \mathrm{Ma}$, the preferred age being $85 \mathrm{Ma}$. On the basis of a K/Ar determination on biotite, Hasui and Cordani (1968) recommended an age of 89 Ma for the Araxá complex.

\section{SAMPLING AND ANALYTICAL PROCEDURES}

The investigated samples came mainly from drillcores, which were taken as part of a geochemical exploration program conducted by the Arafértil S/A mining company; its location is indicated in the simplified geological map of Fig. 2 (after Grossi-Sad \& Torres 1976, in Issa Filho et al. 1984). Surface samples (BAR 1-9) were collected at the northern part of the intrusion. In spite of covering a small area of the whole complex, the available samples are believed to be representative by showing carbonatites and mica-rich rocks, the most significant 


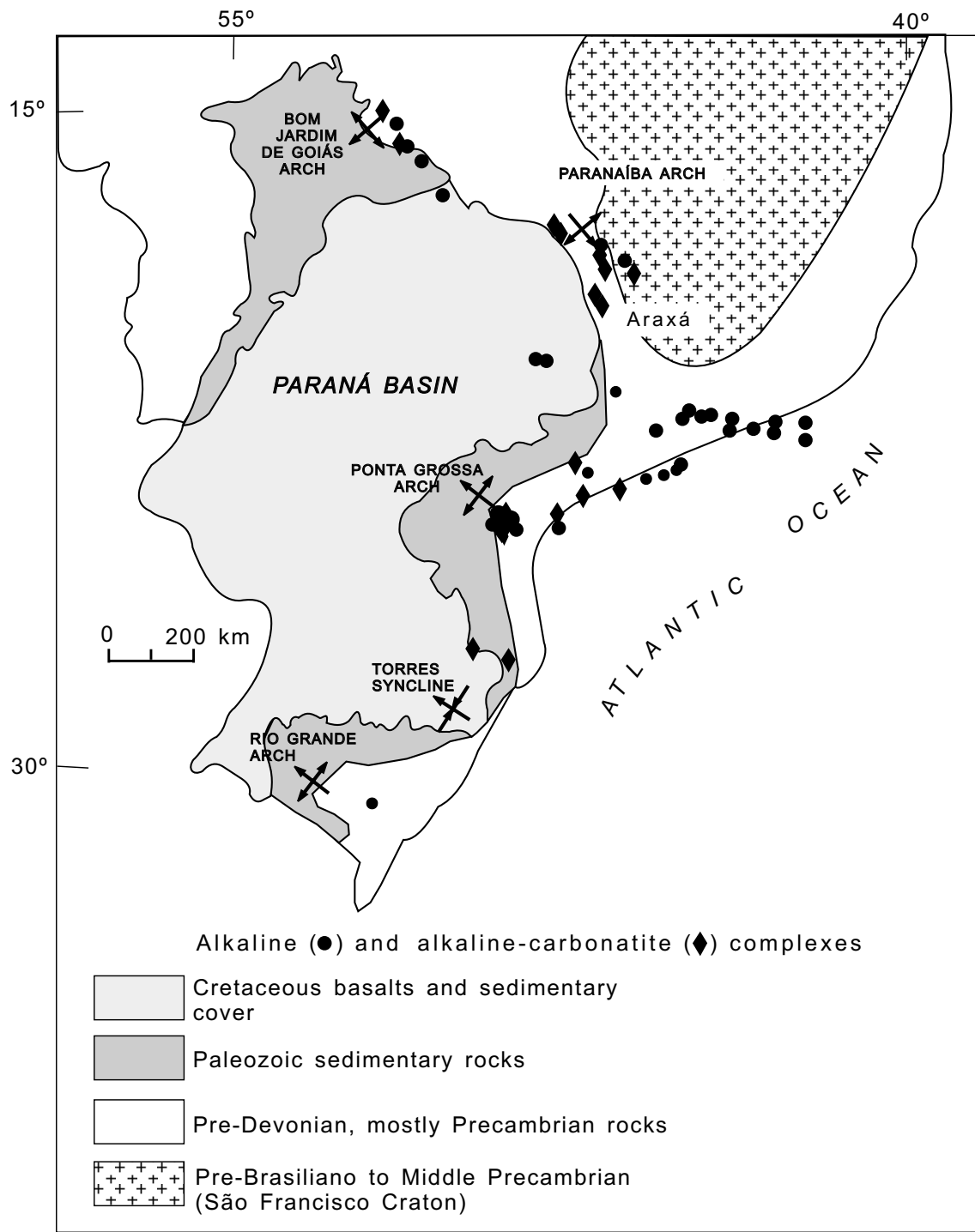

Fig. 1 - Alkaline and alkaline-carbonatite occurrences of southern Brazil (after Ulbrich \& Gomes 1981 simplified). The Araxá complex is also indicated.

Araxá lithological types.

More than 130 samples from 28 different boreholes have been investigated in detail. The analytical program comprised X-ray diffractometric studies and X-ray fluorescence (XRF) analyses for major and trace elements. A representative number of samples was selected for REE determinations using the inductive coupled plasma technique (ICPMS) at Activation Laboratories LTD Ancaster, On- tario, Canada. Additional analytical procedures included the determination of $\mathrm{MgO}$ by atomic absorption, $\mathrm{FeO}$ by titration, L.O.I. by gravimetry and $\mathrm{CO}_{2}$ by gaschromatography. Precision and accuracy for trace elements were better than $10 \%$.

Mineral analyses have been carried out using a Philips 515 scanning electron microscopy fitted with an energy dispersion system (EDAX PV 9000). Information on topographic features were provided 


\section{GEOLOGICAL MAP OF THE BARREIRO COMPLEX}

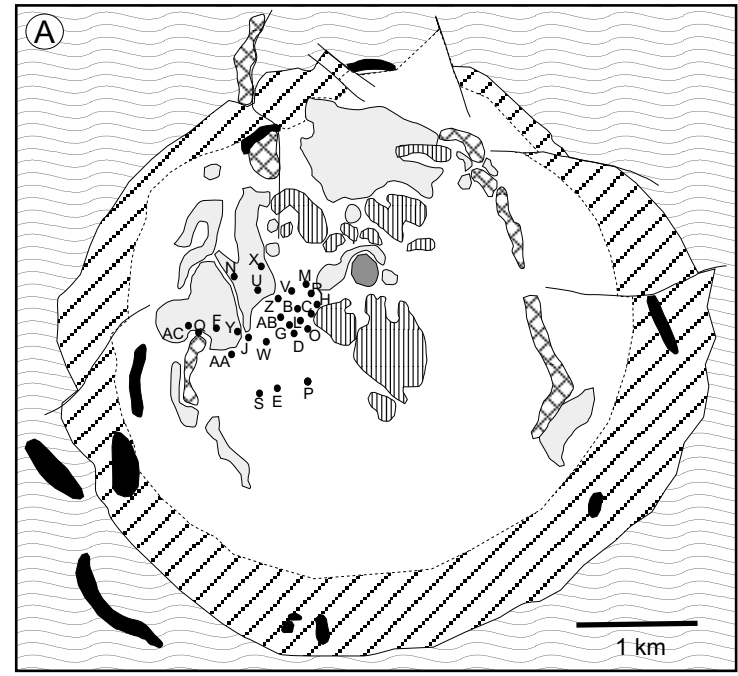

\section{LEGEND}

SUPERFICIAL DEPOSITS

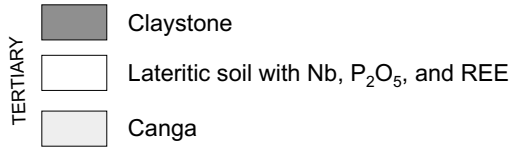

? METASOMATIC ROCKS

Syenitic fenite and

Barite-calcedony-quartz rock

\section{z METASEDIMENTARY ROCKS}

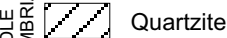 \\ Biotite schist}

MINERAL DEPOSITS
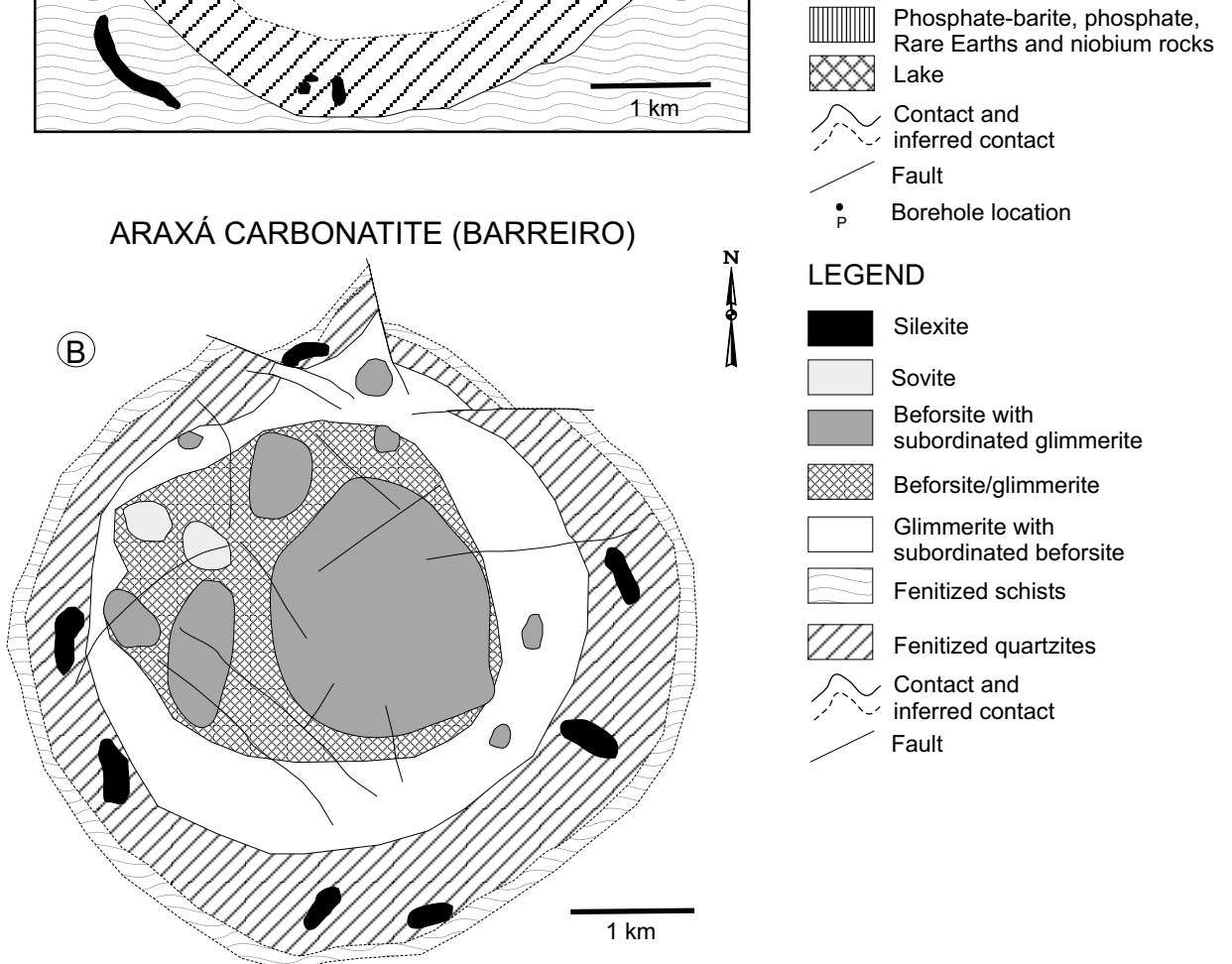

LEGEND

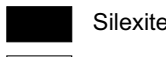

Sovite

Beforsite with

subordinated glimmerite

Beforsite/glimmerite

Glimmerite with

subordinated beforsite

Fenitized schists

2/2 Fenitized quartzites

$\therefore$ Contact and

inferred contact

Fault

Fig. 2 - Schematic interpretation of the Araxá carbonatite geology (after Issa Filho et al. 1984) (A) and surface geological map (after Grossi-Sad \& Torres 1976 simplified) (B). Also shown is the bore-holes area.

by backscattered and secondary electron images. Quantitative data have been corrected for ZAF factors (EDAX PV SUPQ).

Chemical data for carbonates have been recalculated using $\mathrm{CO}_{2}$ mean values from literature (Deer et al. 1964, for calcite, dolomite, ankerite, siderite and magnesite; Speer \& Hensley-Dunn 1976, for strontianite; Platt \& Woolley 1990, for burbankite; Kasputin 1980, for ancylite and breunnerite). For additional minerals (Tables III to V), analyses were 
recalculated to $100 \%$.

\section{PETROGRAPHY}

The Araxá complex is mainly represented by carbonatites and mica-rich rocks; a hybrid rock-type (MC), basically consisting of silicate and carbonate material, is also recognized. On the basis of the Woolley (1982) chemical classification, the carbonatites can be placed into three groups: calciocarbonatites $(\mathrm{CaC})$, magnesiocarbonatites $(\mathrm{MgC})$ and ferrocarbonatites $(\mathrm{FeC})$.

Calciocarbonatites are texturally equigranular, hypidiomorphic to allotriomorphic and have grain size averaging $1-5 \mathrm{~mm}$. Calcite and dolomite, present in variable amounts, make up the principal carbonate minerals, whereas ankerite, siderite, burbankite and ancylite are less frequent; strontianite and carbocernaite occur rarely. Other constituents are phlogopite, apatite, magnetite and arfvedsonite. Monazite, ilmenite, spinel, pyrochlore, rutile, zircon and ore minerals (pyrite and chalcopyrite) are found as accessories; barite, quartz and celadonite constitute the principal secondary phases.

Magnesiocarbonatites, the most abundant carbonatite type, are equigranular, fine-grained and chiefly allotriomorphic in texture. Carbonate phases consist mainly of dolomite with calcite being recognized in a few samples. Additional carbonates only scarcely identified are strontianite, ankerite, burbankite, ancylite, siderite and magnesite. Phlogopite, sometimes reaching large quantities, apatite and magnetite are also present. As accessories are found pyrochlore, rutile, monazite, baritocalcite, huanghoite, tainiolite and norsethite. Secondary phases include barite, quartz and celadonite.

Ferrocarbonatites are clearly subordinate to the previous types. They show similarities in texture, except for the presence in a few samples of large magnetite grains and celadonite-phlogopite aggregates pseudomorphically formed after olivine and pyroxene crystals thereby giving the rocks a porphyritic character. Dolomite is the major carbonate phase, while strontianite, siderite, burbankite and ankerite occur in minor amounts. Phlogopite is al- most absent, whereas apatite is commonly found. Accessory minerals consist of monazite, ilmenite, pyrite, chalcopyrite, sphalerite, galena and cobaltite (?).

The Araxá carbonatitic rocks, which are brecciated, fine to coarse-grained, dark-colored, and strongly enriched in phlogopite and/or apatite and well developed magnetite crystals have been referred to as phoscorites by Issa Filho et al. (1984).

In many Brazilian complexes, carbonatites are closely associated with an ultramafic plutonic assemblage, having pyroxenites (sometimes jacupirangites), dunites, peridotites and glimmerites as important rock-types. There, glimmerites have been interpreted as the result of the phlogopitization of ultrabasic rocks due to the action of carbonatitic liquids (Morbidelli et al. 1986, Gomes et al. 1990).

Mineralogical studies on the Araxá mica-rich rocks allow to distinguish the presence of two micagenerations. The first phase has primary origin and is represented by large (average 1-5 $\mathrm{mm}$ in size), brown, idiomorphic zoned crystals, showing compositional variation from the core (phlogopite) to the rims (tetraferriphlogopite). The second phase is made up of minute brown crystals as small aggregates. They present homogeneous composition (tetraferriphlogopite) and are formed after the replacement of former clinopyroxene and olivine crystals. Mineral relicts are still present, indicating a clear secondary origin for the mica.

In an attempt to better describe the mica-rich rocks, they are here subdivided into two groups, mica-bearing rocks with olivine-clinopyroxene pseudomorphs $(\mathrm{G})$ and mica-olivine pyroxenites (MOP).

The first group is basically constituted by glimmeritic rocks. As a result of late metasomatic processes, they are quite variable in texture and composition. Texture changes from granular to porphyritic, owing to either the presence of large phlogopite grains or aggregates of tetraferriphlogopite (glomerocrysts) originated after the substitution of olivine and clinopyroxene crystals. It can also be cumulitic, as mainly indicated by the concentration 
of aggregates frequently exhibiting layering structures. Cumulus minerals have mica (phlogopite and tetraferriphlogopite at the periphery of grains) as the most abundant phase, olivine and clinopyroxene being only found as relict crystals in association with micaceous material, which includes celadonite, carbonates and amphibole (antophyllite, arvfedsonite); subordinately, apatite and magnetite are also present. Primary intercumulus minerals are poorly defined considering the phlogopitization processes and the pronounced secondary carbonatization of aggregates. In addition to the many types of carbonates (dolomite, ankerite, magnesite, strontianite, breunnerite, ancylite and siderite as minute granular aggregates), these rocks contain opaques (ilmenite, chromite, pyrite, chalcopyrite, sphalerite and millerite), monazite, pyrochlore, zirconolite and calzirtite as accessory phases.

The second group is made up by pyroxenitic rocks showing no evidence of phlogopitization. Texture is characteristically cumulitic with clinopyroxene crystals, peripherically altered to an amphibole of arvfedsonitic composition as the principal cumulus phase; phlogopite and olivine are less abundant. Perovskite, magnetite, apatite and titaniferous garnet in minor amounts are also recognized. Layering can be present as promptly evidenced by monomineralic concentrations of apatite. Grain size of cumulus minerals is quite variable leading to textural changes from equi- to inequigranular (porphyritic), as suggested by large crystals of phlogopite surrounded by tetraferriphlogopite at its margins. The intercumulus assemblage consists mainly of small grains of clinopyroxene and tetraferriphlogopite. Carbonates (calcite, dolomite, ankerite, siderite and burbankite) are widespread and anthophyllite (sometimes talc) and celadonite represent typical alteration products of olivine and clinopyroxene, respectively. As accessories are found ilmenite, rutile, chalcopyrite, calzirtite and zirconolite.

The hybrid rocks show a "biotititic nature" and are characteristically orthocumulitic, with the texture grading from equi- to inequigranular as a result of the size increasing of phlogopite crystals. Cumu- lus phases comprise basically phlogopite; olivine and clinopyroxene, commonly transformed into minute aggregates of tetraferriphlogopite and celadonite, are rare. Large crystals of phlogopite display clear evidence of reabsorption with replenishment by intercumulus material (tetraferriphlogopite). Newly formed grains are perfectly idiomorphic and also poikilitic in texture with inclusions of apatite, perovskite and magnetite. The intercumulus minerals are composed by small crystals of phlogopite and carbonates (calcite and dolomite). However, the main carbonatic phase in these rocks is indicated by the presence of a network of minute veins filled in with carbonates (dolomite, ankerite and rare siderite) and also by many of the accessory minerals previously described in the carbonatites.

\section{MINERAL CHEMISTRY}

\section{Carbonates}

Representative analyses of carbonate minerals from the two principal Araxá lithological groups (carbonatites and mica-rich rocks) are listed in Table I and all data plotted in Fig. 3. Graphs point to the similarity in composition for both groups, where the main differences dealing with the higher dispersion presented by the dolomite $(\mathrm{Mg} / \mathrm{Fe}>4)$ and ankerite $(\mathrm{Mg} / \mathrm{Fe}<4)$ analyses. The greater $\mathrm{Mg}-\mathrm{Fe}$ compositional variation is also put in evidence by the presence of magnesite and breunnerite, in addition to siderite in mica-bearing rocks. On the other hand, only iron-enriched $(\mathrm{FeO} / \mathrm{MgO}>50 \%)$ phases were noticed in carbonatites.

Calcites show homogeneous and limited composition and are, in general, low in $\mathrm{MgO}$ and $\mathrm{FeO}$. The $\mathrm{SrO}$ content is higher than $1 \%$, whereas $\mathrm{MnO}$ is practically absent. Dolomites display a wider compositional field, ranging from pure end-members to more iron-enriched compositions, the latter grading to ankerite types. The $\mathrm{MnO}$ and $\mathrm{SrO}$ proportions are consistently low. Ankerites also show regular contents for those minor elements. As illustrated in Fig. $3 \mathrm{~B}$, the $\mathrm{MgO} / \mathrm{FeO}$ ratio in siderites is variable, the higher values are found in calciocarbonatites. 


\section{TABLE I}

Representative carbonate analyses of Araxá rocks. Abbreviations for mineral names: Cc, calcite; Do,dolomite; Ak, ankerite; Sd, siderite; Ms, magnesite; $\mathrm{Sr}$, strontianite; $\mathrm{Br}$, breunnerite. For rock names: $\mathrm{CaC}$, calciocarbonatites; MgC, magnesiocarbonatites; FeC, ferrocarbonatites; G, glimmerites; MOP, micaolivine pyroxenites; MC, hybrid rocks.

\begin{tabular}{|c|c|c|c|c|c|c|c|c|c|c|}
\hline & $\mathrm{CcCaC}$ & $\mathrm{CcFeC}$ & $\mathrm{CcG}$ & CcMOP & $\mathrm{DoCaC}$ & DoMgC & DoFeC & DoG & DoMOP & DoMC \\
\hline $\mathrm{FeO}$ & & & 0.7 & & 1.8 & 3 & 2.5 & 2 & 0.6 & 2.1 \\
\hline $\mathrm{MnO}$ & & & & & 0.3 & 0.5 & 0.4 & 0.5 & 0.8 & 0.6 \\
\hline $\mathrm{MgO}$ & 0.3 & 0.2 & 1.2 & & 19.5 & 19 & 18.8 & 18.5 & 19.9 & 16.9 \\
\hline $\mathrm{CaO}$ & 55.2 & 54.6 & 53.5 & 55.1 & 31.3 & 29.7 & 31.3 & 31.7 & 31.6 & 32.7 \\
\hline $\mathrm{SrO}$ & 1 & 1.7 & 1.1 & 1.3 & 0.6 & 1.3 & 0.5 & 0.8 & 0.6 & 1.2 \\
\hline \multirow[t]{2}{*}{$\mathrm{CO}_{2}$} & 43.5 & 43.5 & 43.5 & 43.5 & 46.5 & 46.5 & 46.5 & 46.5 & 46.5 & 46.5 \\
\hline & AkCaC & $\mathrm{AkMgC}$ & $\mathrm{AkFeC}$ & $\mathrm{AkG}$ & AkMOP & $\overline{\mathrm{SdCaC}}$ & $\mathrm{SdMgC}$ & $\mathrm{SdFeC}$ & SdG & \\
\hline $\mathrm{FeO}$ & 11.9 & 7.7 & 11 & 10.6 & 7.6 & 49.8 & 30.6 & 40.3 & 41.3 & \\
\hline $\mathrm{MnO}$ & 0.9 & 1.3 & 1.5 & 1.1 & 1.8 & 0.9 & 3.1 & 1.9 & 2 & \\
\hline $\mathrm{MgO}$ & 13.5 & 16.7 & 12.6 & 11.5 & 13.4 & 10.8 & 27.3 & 19.3 & 17.4 & \\
\hline $\mathrm{CaO}$ & 29.3 & 29.5 & 30.3 & 32.1 & 32.2 & 0.2 & 0.4 & 0.2 & 1 & \\
\hline $\mathrm{SrO}$ & 0.1 & 0.5 & 0.3 & 0.4 & 0.7 & & 0.3 & & & \\
\hline \multirow[t]{2}{*}{$\mathrm{CO}_{2}$} & 44.3 & 44.3 & 44.3 & 44.3 & 44.3 & 38.3 & 38.3 & 38.3 & 38.3 & \\
\hline & SdMOP & SdMC & $\mathrm{MsG}$ & $\mathrm{SrCaC}$ & $\mathrm{SrMgC}$ & $\mathrm{SrFeC}$ & $\mathrm{SrG}$ & SrMC & $\mathrm{BrG}$ & \\
\hline $\mathrm{FeO}$ & 37.5 & 35.3 & 4 & 0.2 & & & & & 24.3 & \\
\hline $\mathrm{MnO}$ & 0.6 & 3.3 & 0.9 & & & & & & 0.3 & \\
\hline $\mathrm{MgO}$ & 22.6 & 22.6 & 42.3 & & & & & & 34.2 & \\
\hline $\mathrm{CaO}$ & 1 & 0.6 & 1.4 & 6.5 & 3.5 & 5.6 & 2 & 2.1 & 0.5 & \\
\hline $\mathrm{BaO}$ & & & & 1 & 6.4 & 1.5 & 4.8 & 9.3 & & \\
\hline $\mathrm{SrO}$ & & & & 61.3 & 59.1 & 61.9 & 62.4 & 57.6 & & \\
\hline $\mathrm{CO}_{2}$ & 38.3 & 38.3 & 51.4 & 31 & 31 & 31 & 31 & 31 & 40.6 & \\
\hline
\end{tabular}

Excluded strontianites (concentrations going up to $11.9 \%$ and $9.3 \%$ in samples from mica carbonatite and ferrocarbonatite groups, respectively), the $\mathrm{BaO}$ content is low or even unexistent.

\section{REE CARBONATES}

Here are included primary and secondary minerals in origin, that occur either as isolated grains or small aggregates consisting mainly of minute, needle-shape crystals. Chemical data reported in Table II make possible the characterization of several phases.

Burbankite, a primary mineral frequently found as minor inclusions in calcites and dolomites, shows significant compositional variations. It is REE-poor in calcio- and ferrocarbonatites and strongly enriched of these elements in magnesiocarbonatites and mica-olivine pyroxenites. In the first case, the REE-group is only represented by $\mathrm{Ce}$, whereas in the second one $\mathrm{La}$ and $\mathrm{Nd}$ are also present. An inverse correlation is evidenced by $\mathrm{SrO}$, whose concentration reaches higher values (27$31 \%$ ) in the first rock-types. Additional differences are shown by $\mathrm{BaO}$ and $\mathrm{Na}_{2} \mathrm{O}$. $\mathrm{BaO}$ tends to be more concentrated $(9.5-12.7 \%)$ in samples belonging to the second group. On the other hand, in spite of its irregular behaviour, the $\mathrm{Na}_{2} \mathrm{O}$ content increases in calcio and ferrocarbonatites. The mineral may be found altered into small aggregates of minute crystals of carbocernaite. Chemical analysis of this 

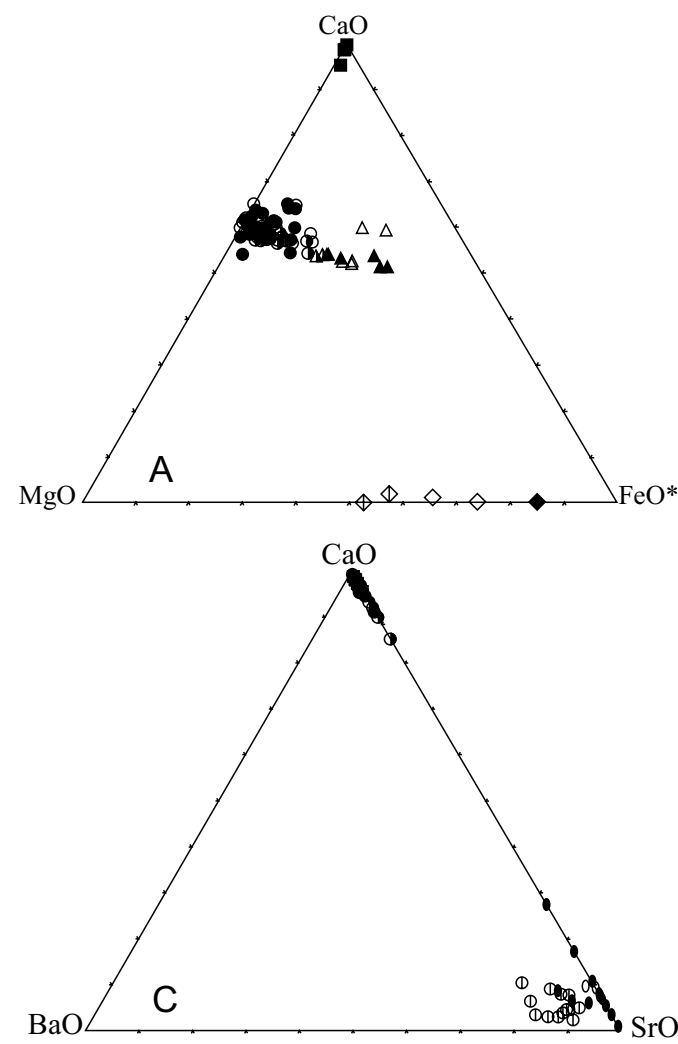
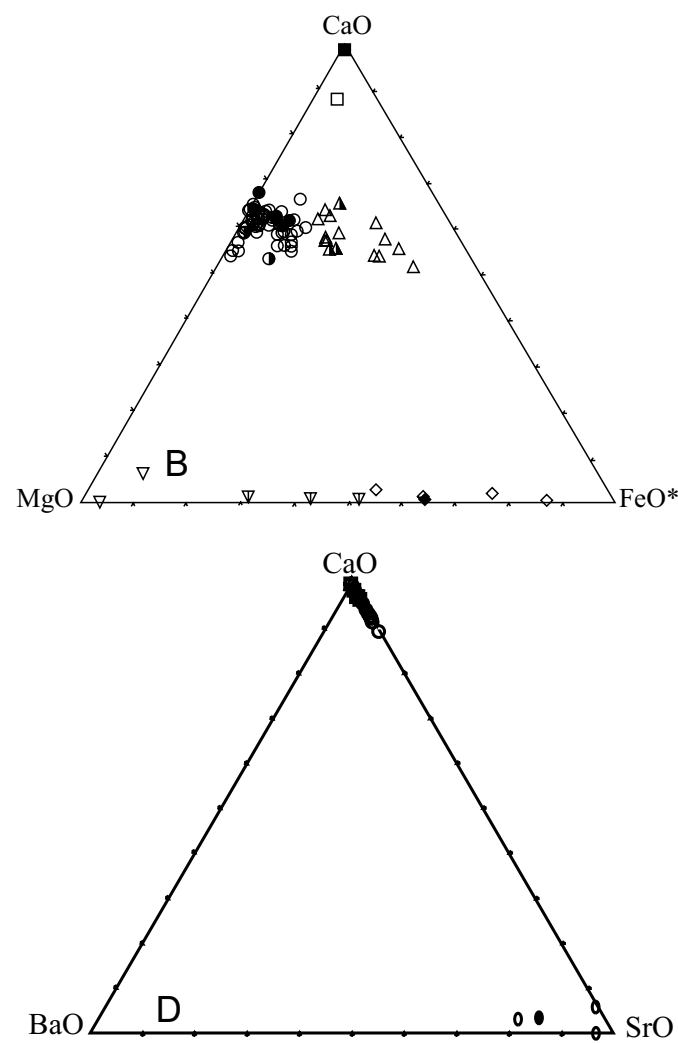

Fig. $3-\mathrm{A})-\mathrm{CaO}-\mathrm{MgO}-\mathrm{FeO} *(\mathrm{FeO} *=\mathrm{FeO}+\mathrm{MnO})$ diagram $(w \mathrm{t} \%)$ of carbonates from Araxá carbonatites. Symbols: full square, $\mathrm{CcCaC}$; empty square, $\mathrm{CcFeC}$; full circle, DoCaC; half full circle, DoMgC; empty circle, $\mathrm{DoFeC}$; full triangle, $\mathrm{AkCaC}$; half full triangle, $\mathrm{AkMgC}$; empty triangle, $\mathrm{AkFeC}$; full diamond, $\mathrm{SdCaC}$; barred empty diamond, SdMgC; empty diamond, SdFeC. For rock and mineral abbreviations see Table I. B) - CaO$\mathrm{MgO}-\mathrm{FeO}^{*}\left(\mathrm{FeO}^{*}=\mathrm{FeO}+\mathrm{MnO}\right)$ diagram $(\mathrm{wt} \%)$ of carbonates from Araxá mica-rich rocks. Symbols: empty square, CcG; full square, CcMOP; empty circle, DoG; half full circle, DoMOP; full circle, DoMC; empty triangle, $\mathrm{AkG}$; half full triangle, AkMOP; empty diamond, SdG; half full diamond, SdMOP; full diamond, SdMC; inverse empty triangle, $\mathrm{MgG}$; barred inverse empty triangle, $\mathrm{BrG}$. C) - $\mathrm{CaO}-\mathrm{BaO}-\mathrm{SrO}$ diagram (wt\%) of carbonates from Araxá carbonatites. Symbols: as in A except for full ovoid, SrCaC; barred empty circle, SrMgC; empty ovoid, $\mathrm{SrFeC}$. D) - CaO-BaO-SrO diagram (wt\%) of carbonates from Araxá mica-rich rocks. Symbols: as in B except for empty ovoid, SrG; full ovoid, SrMC.

phase (Table II) shows similarities relative to the data presented by the burbankite associated to calcio- and ferrocarbonatites. The main difference is the higher carbocernaite content of REE, which is compensated by its sodium deficiency.

Burbankite analyses reported in literature (Khomyakov 1995) differ, in general, in respect to the Araxá minerals, by their higher $\mathrm{Na}_{2} \mathrm{O}, \mathrm{Ce}_{2} \mathrm{O}_{3}$ and $\mathrm{La}_{2} \mathrm{O}_{3}$ and lower $\mathrm{CaO}$ and $\mathrm{SrO}$ contents, re- spectively.

Ancylite as minute crystals is commonly found in association with strontianite. Chemical data (Table II) point to a higher REE concentration for the mineral of magnesiocarbonatites and glimmeritic rocks in comparison to calciocarbonatites. Differences regard mainly the $\mathrm{La}_{2} \mathrm{O}_{3}$ and $\mathrm{Nd}_{2} \mathrm{O}_{3}$ distribution. The $\mathrm{Sr}$ content is high in both cases.

Huanghoite, baritocalcite and norsethite are 


\section{TABLE II}

Representative REE carbonate analyses (burbankite, 1-8; ancylite, 9-15; carbocernaite, 16; huanghoite, 17; baritocalcite, 18-19; norsethite, 20) of Araxá rocks. For rock abbreviations see Table I.

\begin{tabular}{|c|c|c|c|c|c|c|c|c|c|c|}
\hline & 1 & 2 & 3 & 4 & 5 & 6 & 7 & 8 & 9 & 10 \\
\hline & $\mathrm{CaC}$ & $\mathrm{CaC}$ & $\mathrm{CaC}$ & $\mathrm{CaC}$ & $\mathrm{MgC}$ & $\mathrm{MgC}$ & $\mathrm{FeC}$ & MOP & $\mathrm{CaC}$ & $\mathrm{CaC}$ \\
\hline & BY7A & BY7B & BU2A & $\mathrm{BU} 2 \mathrm{~B}$ & $\mathrm{BB} 2 \mathrm{~A}$ & $\mathrm{BB} 2 \mathrm{~B}$ & BAR9D & BAC1 & BC7A & BC7B \\
\hline $\mathrm{La}_{2} \mathrm{O}_{3}$ & & & & & 7.8 & 8.3 & & 3.8 & 11 & 14.5 \\
\hline $\mathrm{Ce}_{2} \mathrm{O}_{3}$ & 5.3 & & 3 & 3 & 11.5 & 11.4 & 1.4 & 10.4 & 31.4 & 32.8 \\
\hline $\mathrm{Nd}_{2} \mathrm{O}_{3}$ & & & & & 0.9 & 2 & & 2.4 & 9.9 & 9.6 \\
\hline $\mathrm{TiO}_{2}$ & 2.5 & & & & & & & & & \\
\hline $\mathrm{FeO}$ & & & & & & & & & 2.9 & \\
\hline $\mathrm{CaO}$ & 16.7 & 16.4 & 22.4 & 19.3 & 11.1 & 11.7 & 21 & 8.1 & 1 & 0.8 \\
\hline $\mathrm{SrO}$ & 29.4 & 31.1 & 27.2 & 31 & 17 & 17.6 & 26.8 & 22.3 & 22.8 & 21.4 \\
\hline $\mathrm{BaO}$ & & 6.2 & 7 & 6.8 & 9.5 & 9.9 & 7.3 & 12.7 & & \\
\hline $\mathrm{Na}_{2} \mathrm{O}$ & 10.5 & 10.8 & 4.9 & 4.3 & 7.1 & 4.1 & 8 & 4.4 & & \\
\hline $\mathrm{K}_{2} \mathrm{O}$ & 0.1 & & & & 0.5 & 0.5 & & 0.5 & & \\
\hline \multirow[t]{4}{*}{$\mathrm{CO}_{2}$} & 35.5 & 35.5 & 35.5 & 35.5 & 35.5 & 35.5 & 35.5 & 35.5 & 21 & 21 \\
\hline & 11 & 12 & 13 & 14 & 15 & 16 & 17 & 18 & 19 & 20 \\
\hline & $\mathrm{MgC}$ & $\mathrm{MgC}$ & $\mathrm{MgC}$ & G & $\mathrm{MC}$ & $\mathrm{CaC}$ & $\mathrm{MgC}$ & $\mathrm{MgC}$ & $\mathrm{MgC}$ & $\mathrm{MgC}$ \\
\hline & $\mathrm{BO} 2 \mathrm{BA}$ & $\mathrm{BO} 2 \mathrm{BB}$ & BR1 & BR3 & BL9 & BU1 & BR4 & BR1A & BR1B & BR4 \\
\hline $\mathrm{La}_{2} \mathrm{O}_{3}$ & 25.4 & 17.3 & 23.9 & 20 & 24 & 2.4 & & & & \\
\hline $\mathrm{Ce}_{2} \mathrm{O}_{3}$ & 31.5 & 32.7 & 33.4 & 33.1 & 32.8 & 8.4 & 15.7 & & & \\
\hline $\mathrm{Nd}_{2} \mathrm{O}_{3}$ & 1.8 & 6.6 & 4.2 & 3.7 & 2.6 & & 10.6 & & & \\
\hline $\mathrm{FeO}$ & & & & 2.7 & & & & & & 2.2 \\
\hline $\mathrm{MgO}$ & & & & & & & & & & 15.2 \\
\hline $\mathrm{CaO}$ & 0.4 & 0.4 & 0.9 & 1.1 & & 23.2 & 2.9 & 15.2 & 13 & \\
\hline $\mathrm{SrO}$ & 20 & 22.1 & 16.6 & 18.4 & 19.6 & 25.4 & 7.7 & 9.3 & 14.4 & \\
\hline $\mathrm{BaO}$ & & & & & & 6.6 & 43.1 & 45 & 42.1 & 52.7 \\
\hline \multicolumn{11}{|l|}{$\mathrm{Na}_{2} \mathrm{O}$} \\
\hline \multicolumn{11}{|l|}{$\mathrm{K}_{2} \mathrm{O}$} \\
\hline $\mathrm{CO}_{2}$ & 21 & 21 & 21 & 21 & 21 & 34 & 20 & 30.5 & 30.5 & 30 \\
\hline
\end{tabular}

Ba-rich (> 40\%) phases (Table II) of secondary origin, rare occurrence and only identified in magnesiocarbonatites. The first mineral contains a significant amount of REE, whereas the second one consists of a Ca-Ba carbonate, also Sr-bearing. Data from literature (Kasputin 1980) show SrO values normally lower than $2 \%$. Norsethite is essentially an $\mathrm{Mg}-\mathrm{Ba}$ carbonate with low $\mathrm{FeO}$ content.

\section{Phosphates}

Apatite is by far the most common and important phosphate mineral in Araxá rocks. In general, it makes up idiomorphic and prismatic crystals that occur either isolatedly or forming unimineralic concentrations. As cumulus phase, the mineral is mainly found associated with carbonatites, but also with mica-rich rocks. Chemical composition is regular, with large amounts of $\mathrm{P}_{2} \mathrm{O}_{5}$ and $\mathrm{CaO}$. As a rule, the $\mathrm{SrO}$ content remains in the range of $3-5 \%$, but can go up to $10 \%$ in some cases forming Sr-enriched apatites. Secondary phosphates are widespread and chiefly represented by Al-bearing phases. 
Monazite is the principal REE-phosphate present in the investigated rocks. Selected analyses indicate $\mathrm{Ce}_{2} \mathrm{O}_{3}$ as the most abundant RE element, with the concentration going up to $37 \%$ in glimmerites; that particular sample shows higher $\mathrm{SrO}$ and $\mathrm{BaO}$ values and also contains $4.8 \% \mathrm{ThO}_{2}$. Despite the non-uniform composition of monazite, no systematic variation is indicated for the two lithological groups.

\section{SiliCATES}

Except for nenadkevichite, chemical data on silicate minerals are not listed in tables and only the micas plotted on the available graphs.

\section{Olivines, clinopyroxenes and amphiboles}

Fresh olivines are essentially restricted to the micaolivine pyroxenites. Composition is homogeneous lying within a narrow interval, $\mathrm{Fo}_{86-92}$. $\mathrm{CaO}$ stands normally below $1 \%$. The mineral can be found either altered into anthophyllite in pyroxenitic rocks or phlogopite-celadonite aggregates in glimmeritic rocks.

Clinopyroxenes also have uniform composition, with the data plotting on the diopside field. The $\mathrm{FeO}$ content is low and $\mathrm{FeO} / \mathrm{Fe}_{2} \mathrm{O}_{3}$ partitioning follows to Papike et al. (1974). Other analyzed elements, such as $\mathrm{TiO}_{2}$ and $\mathrm{Al}_{2} \mathrm{O}_{3}$, show values lower than $1.3 \%$ and $1.8 \%$, respectively.

The amphiboles are secondary minerals mainly represented by two distinctive and characteristic types, magnesioarfvedsonite and antophyllite (Leake et al. 1997). The first phase is a common mineral to carbonatites and glimmeritic rocks, being acicular in shape and clearly derived from clinopyroxene crystals. Chemical composition indicates a large variation in $\mathrm{FeO}$ (1.1-17.3\%), $\mathrm{MgO}$ (14.4$25.9 \%)$ and $\mathrm{Na}_{2} \mathrm{O}(3.4-6.2 \%)$ contents. The mineral also bears high $\mathrm{CaO}$ and $\mathrm{K}_{2} \mathrm{O}$ amounts. On the other hand, anthophyllite is basically a ferromagnesian phase with small contributions of $\mathrm{CaO}$ $(<1.8 \%)$ and $\mathrm{K}_{2} \mathrm{O}(<1.9 \%)$. It should be noted that the amphiboles in Araxá rocks are Al-poor phases.
Thus, during crystallization processes the available $\mathrm{Al}$ would be principally destinated to the mica formation.

\section{Micas}

Micas are a very important mineral constituent, being represented by phlogopite and tetraferriphlogopite, the latter an intercumulus primary phase, but mainly found as small aggregates of secondary origin, and celadonite as the most common alteration product. Chemical analyses are plotted on the conventional $\mathrm{Al}-\mathrm{Mg}-\mathrm{Fe}^{2+}$ diagram (Figs. 4A, B). In general, early phlogopite, a high $\mathrm{Al}_{2} \mathrm{O}_{3}$ and low $\mathrm{FeO}$ phase, can be found grading progressively into tetraferriphlogopite as a result of Al-deficiency during the magmatic crystallization, which is in turn compensated by the $\mathrm{Fe}^{3+}$ entry occupying tetrahedral sites in the mineral structure. Figs. 4C, D, relating $\mathrm{Si}$ against $\mathrm{Al}^{\mathrm{IV}}$, put in evidence such deficiency. This particular feature has also been observed in other Brazilian alkaline-carbonatite occurrences, as emphasized by Morbidelli et al. (1995, 1997). Those chemical variations are followed by optical changes in the mineral as indicated by the inverse pleochroism normally exhibited by tetraferriphlogopite. Chemical data also draw the attention to the transformation of phlogopite into tetraferriphlogopite, the latter phase mainly occupying the periphery of grains and/or being concentrated along the cleavage planes. No significant differences in mica composition have been detected for the two lithological groups.

In Araxá rocks celadonite, commonly forming minute grains, is found associated to tetraferriphlogopite and ankerite as an alteration product of primary mafic minerals or even filling late veins, particularly those of ferrocarbonatites. The mineral presents variable $\mathrm{FeO} / \mathrm{MgO}$ ratio and is highly potassic in respect to the data given in literature. Apparently, two types can be distinguished on the basis of $\mathrm{SiO}_{2}$ and $\mathrm{MgO}$ contents, but the available data are still insufficient to draw conclusions.

A rare Li-bearing phase has been identified as 

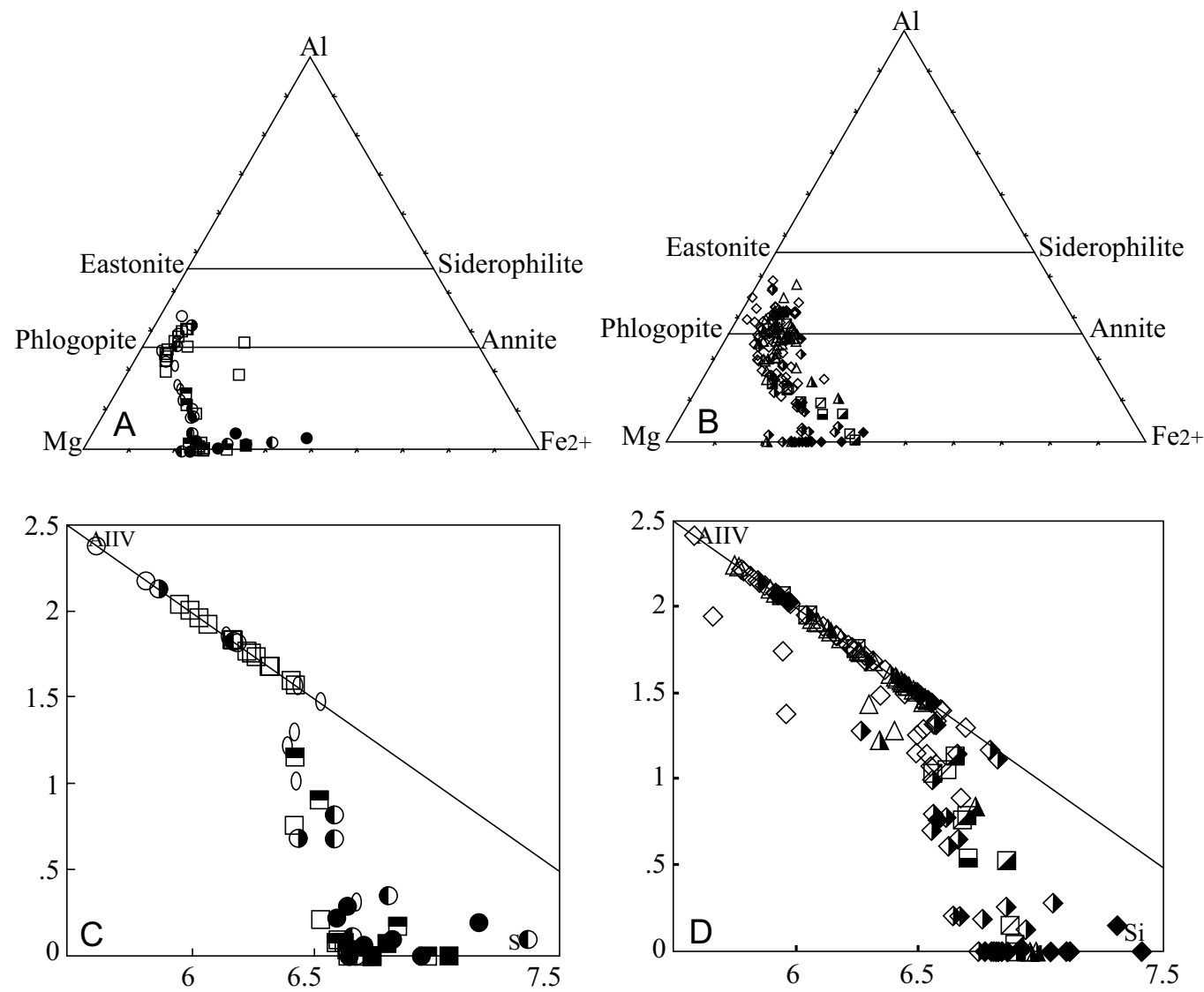

Fig. 4 - A) - Composition of phlogopites and tetraferriphlogopites from Araxá carbonatites plotted on the conventional Al-Mg-Fe ${ }^{2+}$ diagram. Symbols: empty square, $\mathrm{CaC}$, core; half full square, $\mathrm{CaC}$, rim; full square, $\mathrm{CaC}$, ps; empty circle, $\mathrm{MgC}$, core; left, half full circle, $\mathrm{MgC}$, rim; empty ovoid, FeC, core; right, half full circle, FeC, rim; full circle, FeC, ps. Ps, pseudomorphs. B) - Composition of phlogopites and tetraferriphlogopites from Araxá mica-rich rocks plotted on the conventional Al-Mg-Fe ${ }^{2+}$ diagram. Symbols: empty diamond, G, core; half full diamond, G, rim; full diamond, G, ps; empty triangle, MOP, core; half full triangle, MOP, rim; barred empty square, MC, core; transverse half full square, MC, rim; half full square, MC, ps. C) - Composition of phlogopites and tetraferriphlogopites from Araxá carbonatites plotted on the $\mathrm{Al}^{\mathrm{IV}}$-Si diagram. Symbols as in A. D) - Composition of phlogopites and tetraferriphlogopites from Araxá mica-rich rocks plotted on the $\mathrm{Al}^{\mathrm{IV}}$-Si diagram. Symbols as in $\mathrm{B}$.

accessory forming aggregates of acicular crystals in only two samples of magnesiocarbonatites. It is thought to belong to the lepidolite group as indicated by preliminary studies (Table III). A chemically similar mineral is referred to as tainiolite in literature and was described for the first time in 1938 in the alkaline district of Magnet Cove, USA, by Miser and Stevens (Foster 1960, Erd et al. 1983).

\section{Garnet}

This mineral has been described as an accessory phase in some mica-olivine pyroxenites, where it occurs associated to perovskite and opaque grains. It is basically a Ti-bearing andradite, with $\mathrm{TiO}_{2}$ almost constant (10-11\%), and referred to as melanite. A second Ti-andradite phase, but containing a large amount of $\mathrm{ZrO}_{2}(11.3 \%)$, is also present. Acccord- 


\section{TABLE III}

Representative tainiolite (1-2) and nenadkevikite (4-5) analyses of Araxá rocks. For rock abbreviations see Table I. For comparison, mineral analyses from Magnet Cove and Lovozero rocks, respectively.

\begin{tabular}{|c|c|c|c|c|c|c|}
\hline & $\begin{array}{r}1 \\
\mathrm{MgC} \\
\text { BR5A }\end{array}$ & $\begin{array}{r}2 \\
\mathrm{MgC} \\
\text { BR5B }\end{array}$ & $\begin{array}{r}3 \\
\text { Magnet } \\
\text { Cove }\end{array}$ & $\begin{array}{r}4 \\
\mathrm{CaC} \\
\text { BAR1A }\end{array}$ & $\begin{array}{r}5 \\
\text { CaC } \\
\text { BY6 }\end{array}$ & $\begin{array}{r}6 \\
\text { Lovozero } \\
\text { Massif }\end{array}$ \\
\hline $\mathrm{Nb}_{2} \mathrm{O}_{5}$ & & & & 34.7 & 37.6 & 24.05 \\
\hline $\mathrm{SiO}_{2}$ & 60.8 & 59.1 & 58.82 & 39.3 & 37.9 & 37.72 \\
\hline $\mathrm{TiO}_{2}$ & & & 0.11 & 1.6 & 0.3 & 9.69 \\
\hline $\mathrm{Al}_{2} \mathrm{O}_{3}$ & & 0.7 & 1.29 & & & 0.62 \\
\hline $\mathrm{Fe}_{2} \mathrm{O}_{3}$ & & & 0.4 & & & \\
\hline $\mathrm{FeO}$ & 0.8 & 1.1 & 0.24 & & & \\
\hline $\mathrm{MnO}$ & & & & & & 1.08 \\
\hline $\mathrm{MgO}$ & 19.6 & 20.3 & 19.18 & & & 0.45 \\
\hline $\mathrm{CaO}$ & & & & & & 4.3 \\
\hline $\mathrm{Na}_{2} \mathrm{O}$ & & & 0.64 & & & 3.34 \\
\hline $\mathrm{K}_{2} \mathrm{O}$ & 11.8 & 11.8 & 10.44 & 14.4 & 14.2 & 2.68 \\
\hline $\mathrm{Li}_{2} \mathrm{O}$ & 3 & 3 & 3.1 & & & \\
\hline $\mathrm{H}_{2} \mathrm{O}$ & 4 & 4 & & 10 & 10 & 11.34 \\
\hline $\mathrm{BaO}$ & & & & & & 2.75 \\
\hline REE & & & & & & 0.25 \\
\hline Total & 100 & 100 & 94.22 & 100 & 100 & 99.67 \\
\hline
\end{tabular}

ing to the literature (Milton et al. 1961), the mineral can be more properly named ferric-kimzeyite.

\section{Nenadkevichite}

As an accessory phase, certainly of secondary origin, the mineral is found as minute inclusions in late apatite aggregates from calciocarbonatites. Table III lists the obtained chemical data and also an analysis of Kouzmenko from the Lovozero massif, Russia (Karup-Møller 1986). The Araxá mineral is strongly potassic and more $\mathrm{Nb}$-enriched in comparison to the Russian material and also additionally contains very low $\mathrm{TiO}_{2}$ and no $\mathrm{CaO}$ and $\mathrm{Na}_{2} \mathrm{O}$ whatsoever.

\section{OXIDES}

\section{Pyrochlore}

It makes up the principal accessory of Araxá rocks and is mainly found in glimmeritic rocks and carbonatites, particularly the Mg-rich types. The mineral is widespread as minute isolated grains, but also occurs in association with carbonates. Chemical composition is strongly variable and based on its considerable high $\mathrm{Nb}_{2} \mathrm{O}_{5}$ and low $\mathrm{TiO}_{2}$ contents, the mineral is placed into the $\mathrm{Nb}+\mathrm{Ta}>2 \mathrm{Ti}, \mathrm{Nb}>\mathrm{Ta}$ group (Hogarth 1977). Ta concentration is very low and normally below the detectable limit.

Site $\mathrm{A}$ in the mineral structure is in general occupied by $\mathrm{Ca}, \mathrm{Sr}, \mathrm{Ba}$ and $\mathrm{Ce}$, but these elements vary considerably in concentration and may not necessarily be present in the same crystal. Owing to these strong variations in composition, some types could be more properly named bariopyrochlore, ceriopyrochore or even strontiopyrochlore. High $\mathrm{Ba}$ concentration in pyrochlore is believed to be an indicative evidence of its secondary origin (Heinrich 1980, Mariano 1989). In fact, bariopyrochlore is the most important mineral of the pyrochlore group at the Araxá mine (Hogarth 1977) and it is interpreted 
by Heinrich (1980) as a product of hydrothermal activities. In some glimmeritic rocks and also in one sample of magnesiocarbonatite, the $\mathrm{BaO}$ content lies over $10 \mathrm{wt} \%$, occasionally reaching $23 \mathrm{wt} \%$. The chemical data also point to the presence of $\mathrm{Na}_{2} \mathrm{O}$ and $\mathrm{ThO}_{2}$, the maximum values obtained being 7.4 $\mathrm{wt} \%$ and $3.3 \mathrm{wt} \%$ in glimmeritic rocks and magnesiocarbonatites, respectively.

\section{Perovskite}

It is an accessory phase found in mica-olivine pyroxenites in association with titaniferous garnet and opaques. The mineral has a very uniform composition with $\mathrm{TiO}_{2}$ and $\mathrm{CaO}$ as major components. Sporadically, $\mathrm{FeO}$ and $\mathrm{SrO}$ are present in minor amounts.

\section{Rutile}

The mineral is widespread in Araxá rocks, where it occurs as an accessory phase commonly forming isolated grains. In general, it contains $\mathrm{TiO}_{2}$ content over to $90 \mathrm{wt} \%$ and $\mathrm{FeO}$ as the second major component. $\mathrm{Nb}_{2} \mathrm{O}_{5}$ is invariably present, the concentration going up to $9 \mathrm{wt} \%$. On the other hand, $\mathrm{Ta}_{2} \mathrm{O}_{5}$ is rare and only detected in a few samples of calciocarbonatites. $\mathrm{CaO}$ is lower than $1 \mathrm{wt} \%$.

\section{Magnetite, ilmenite and chromite}

Magnetite and ilmenite are very common phases, whereas chromite is scarce and only identified in glimmeritic rocks. Magnetite forms large grains in ferrocarbonatites. The $\mathrm{FeO} / \mathrm{TiO}_{2}$ ratio is almost constant in magnetite (ulvöspinel molecule ranging between $5-30 \%$ in carbonatites, $0-31 \%$ in glimmerites and $0-44 \%$ in pyroxenitic rocks) but quite variable in ilmenite, placing the composition between the members $\mathrm{FeO} . \mathrm{TiO}_{2}$ and $\mathrm{FeO} .2 \mathrm{TiO}_{2}$. In magnetite, $\mathrm{MnO}$ and $\mathrm{MgO}$ are present in minor amounts, the concentration, however, goes up in ilmenite to $6.4 \mathrm{wt} \%$ and $12 \mathrm{wt} \%$, respectively. The $\mathrm{Cr}_{2} \mathrm{O}_{3}$ content of magnetite is normally lower than $2 \mathrm{wt} \%$; in a few samples of pyroxenitic and glimmeritic rocks it is higher, in the range of 5-9 wt $\%$.

\section{Calzirtite and zirconolite}

They form accessory minerals in glimmeritic and mica-olivine pyroxenitic rocks; more rarely, they occur in calciocarbonatites. The calzirtite grains do not show much variation in chemical composition, which basically consists of $\mathrm{TiO}_{2}, \mathrm{CaO}$ and $\mathrm{ZrO}_{2}$ (Table IV). Keller and Schleicher (1990) reported an analysis of Brettel, Germany, bearing $67 \%$ $\mathrm{ZrO}_{2}$, high $\mathrm{Nb}_{2} \mathrm{O}_{5}$ and small amounts of $\mathrm{TiO}_{2}$ and $\mathrm{CaO}$.

\section{TABLE IV}

Representative calzirtite (1-4) and zirconolite (510) analyses of Araxá rocks. For rock abbreviations see Table $\mathrm{I}$.

\begin{tabular}{l|rrrrr}
\hline & 1 & 2 & 3 & 4 & 5 \\
& $\mathrm{G}$ & $\mathrm{G}$ & $\mathrm{MOP}$ & $\mathrm{MOP}$ & MOP \\
& $\mathrm{B} 16 \mathrm{~A}$ & $\mathrm{~B} 16 \mathrm{~B}$ & $\mathrm{BS} 2$ & $\mathrm{BM} 5$ & $\mathrm{BM} 5$ \\
\hline $\mathrm{TiO}_{2}$ & 16.3 & 16.4 & 14.9 & 18.4 & 42.3 \\
$\mathrm{FeO}$ & 1.3 & 1.5 & & 0.8 & 4.8 \\
$\mathrm{CaO}$ & 13.8 & 14.4 & 12.2 & 13.6 & 16.6 \\
$\mathrm{ZrO}{ }_{2}$ & 68.6 & 67.8 & 72.9 & 67.3 & 36.3 \\
\hline \hline & 6 & 7 & 8 & 9 & 10 \\
& $\mathrm{G}$ & $\mathrm{G}$ & $\mathrm{G}$ & $\mathrm{G}$ & $\mathrm{G}$ \\
& $\mathrm{BO} 4$ & $\mathrm{BQ} 1$ & $\mathrm{BQ} 3$ & $\mathrm{~B} 16 \mathrm{~A}$ & $\mathrm{~B} 16 \mathrm{~B}$ \\
\hline $\mathrm{SiO}_{2}$ & 5.1 & & & & \\
$\mathrm{TiO}_{2}$ & 37.5 & 19.7 & 26.8 & 25.8 & 24.2 \\
$\mathrm{FeO}$ & 4.1 & 7.9 & 7.6 & 8.3 & 7 \\
$\mathrm{CaO}$ & 14 & 13 & 13.3 & 13.2 & 12.3 \\
$\mathrm{ZrO}_{2}$ & 38.8 & 32.6 & 29.5 & 30.4 & 36.6 \\
$\mathrm{Nb}_{2} \mathrm{O}_{5}$ & & 22.2 & 20.2 & 18.3 & 14.6 \\
$\mathrm{Nd}_{2} \mathrm{O}_{3}$ & & & & 2.4 & 2.1 \\
$\mathrm{Ce}_{2} \mathrm{O}_{3}$ & 0.7 & & & & \\
$\mathrm{ThO}_{2}$ & & 2.1 & 2.6 & 1.5 & 3.1 \\
\hline
\end{tabular}

The Araxá zirconolite, on its turn, is characterized by higher $\mathrm{TiO}_{2}$ and lower $\mathrm{ZrO}_{2}$ contents regarding the calzirtite (Table IV). Zirconolite also contains $\mathrm{Nb}_{2} \mathrm{O}_{5}$ (15-22\%), $\mathrm{FeO}$ and $\mathrm{ThO}_{2}$ (1.5-3.1\%). The phase described in Eichholz and Brettel rocks (Keller \& Schleicher 1990) contains variable $\mathrm{Nb}_{2} \mathrm{O}_{5}$ 
(16-22\%) and, additionally, $\mathrm{ThO}_{2}(4-5 \%)$ and $\mathrm{UO}_{2}$ $(1.2-1.8 \%)$.

\section{SULPHIDES}

Except for mica-olivine pyroxenites having chalcopyrite as the main sulphide phase, pyrite is widespread in Araxá rocks. Chalcopyrite is also found in carbonatites and glimmeritic rocks. Both minerals show a simple and monotonous composition.

Additional sulphide minerals include sphalerite and galena in carbonatites and glimmerites and, more rarely, cobaltite (?), also bearing a large amount of As, and millerite in ferrocarbonatites and glimmeritic rocks, respectively.

\section{PETROCHEMISTRY}

Representative chemical analyses for major and trace elements of carbonatites and mica-rich rocks are given in Tables V and VI. Data on carbonatites are plotted on the Woolley and Kempe's (1989) classificatory diagram (Fig. 5). In general, the carbonatites lie over the $50 \% \mathrm{CaO}$ reference line, whereas the mica-rich rocks, except for a few samples, are placed below that value.

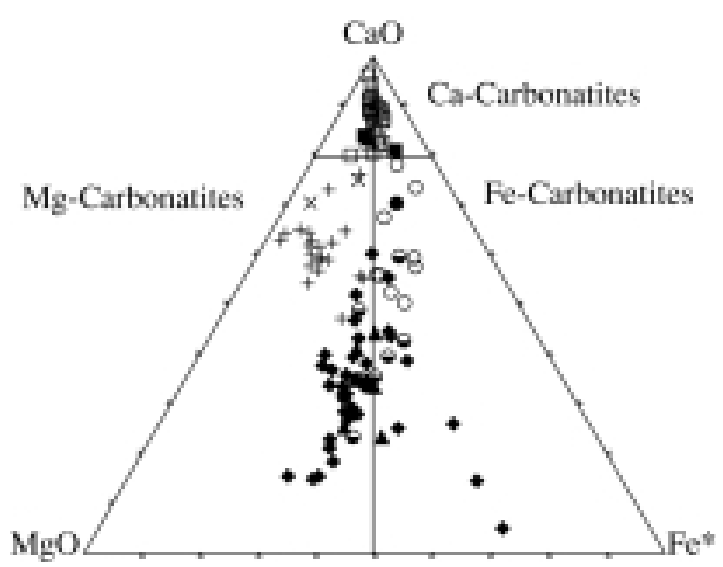

Fig. 5 - Composition of carbonatites and mica-rich rocks from Araxá plotted on the Woolley and Kempe's (1989) CaO-MgO$\mathrm{Fe}^{*}\left(\mathrm{Fe}^{*}=\mathrm{FeO}+\mathrm{Fe}_{2} \mathrm{O}_{3}+\mathrm{MnO}\right)$ diagram (wt $\left.\%\right)$. Symbols: empty square, $\mathrm{CaC}$; full square, $\mathrm{CaC}, \mathrm{Ph}$; vertical cross, $\mathrm{MgC}$; inclined cross, $\mathrm{MgC}, \mathrm{Ph}$; empty circle, $\mathrm{FeC}$; full circle, $\mathrm{FeC}, \mathrm{Ph}$; full diamond, G; half full circle, MOP; full triangle, MC. Ph, phoscorites.
Average compositions (major and trace elements by XRF) for the main Araxá rock-types are shown in Fig. 6. Carbonatites and mica-rich rocks, here included the hybrid lithotypes, are promptly distinguished on the basis of elemental distribution. It should be emphasized that the mica-rich rocks are quite homogeneous in composition and contain high contents of $\mathrm{Cr}$ and $\mathrm{Ni}$; notably they are also enriched in $\mathrm{Zr}, \mathrm{Nb}$, $\mathrm{La}$ and $\mathrm{Ce}$. The carbonatites, on the other hand, are strongly concentrated in $\mathrm{La}$ and $\mathrm{Ce}$.

A negative correlation $\mathrm{CaO}-\mathrm{MgO}$ (Fig. 7), which can be referred to as mineral ratios (e.g. calcite/dolomite in carbonatites and carbonate/phlogopite in mica-rich rocks), characterizes all the lithotypes. The second mineral relationship is also confirmed by the negative $\left(\mathrm{CaO}-\mathrm{SiO}_{2}\right)$ and positive $\left(\mathrm{K}_{2} \mathrm{O}-\mathrm{MgO}\right.$ and $\mathrm{K}_{2} \mathrm{O}-\mathrm{SiO}_{2}$ ) correlations (Fig. 7). In addition, a $\mathrm{CaO}-\mathrm{MgO}-\mathrm{K}_{2} \mathrm{O}$ diagram (not shown) draws the attention to the small phlogopite participation in carbonatites in respect to the mica-rich rocks.

Diagrams normalized according to the Woolley and Kempe's (1989) average compositions for CaC, $\mathrm{MgC}$ and $\mathrm{FeC}$ (Fig. 8) indicate that the Araxá rocks are less rich in $\mathrm{V}, \mathrm{Zn}, \mathrm{Rb}$ and $\mathrm{Pb}$. In contrast, they contain larger amounts of $\mathrm{Cu}$, the enrichment factors being from at least 2 up to 6.3 in $\mathrm{FeC}$. $\mathrm{Zr}$ enrichment is also present in $\mathrm{FeC}$.

$\mathrm{P}_{2} \mathrm{O}_{5}$ values for the Araxá carbonatites are close to the data reported by Woolley and Kempe (1989). Phoscoritic rocks associated to $\mathrm{CaC}$ show the highest $\mathrm{P}_{2} \mathrm{O}_{5}$ contents $(16.97-17.40 \%)$. On the other hand, phoscorites related to $\mathrm{MgC}$ and $\mathrm{FeC}$ contain minor amounts of the element, in general, not over $12 \%$.

$\mathrm{Al}_{2} \mathrm{O}_{3}$ and $\mathrm{K}_{2} \mathrm{O}$ contents are low, as suggested by the dominant nature of the mica (tetraferriphlogopite) present in the carbonatites.

$\mathrm{Nb}$ mineralization is the most important feature regarding the Araxá carbonatites. Brazil is the first $\mathrm{Nb}$ exporter in the world, with the Araxá ore representing about $90 \%$ of the whole production. Contrasting to such situation, the analyzed samples have significantly lower $\mathrm{Nb}$ contents in relation to the 


\section{TABLE V}

Representative bulk-chemical analyses of Araxá carbonatites (1, CaCPh; 2-6, CaC; 7-12, MgC; 13, FeC; 14, FeCPh; 15-17, FeC). For rock abbreviations see Table I; Ph, phoscorites. Major and trace elements in wt\% and ppm, respectively.

\begin{tabular}{|c|c|c|c|c|c|c|c|c|c|}
\hline & 1 & 2 & 3 & 4 & 5 & 6 & 7 & 8 & 9 \\
\hline & BB3 & BC6 & BF3 & BM1 & $\mathrm{BO} 3 \mathrm{~b}$ & BY8 & BA2 & $\mathrm{BC} 1$ & B14 \\
\hline $\mathrm{SiO}_{2}$ & 1.29 & 1.75 & 3.74 & 1.08 & 0.33 & 0.45 & 1.88 & 0.67 & 0.09 \\
\hline $\mathrm{TiO}_{2}$ & 0.20 & 0.17 & 0.44 & 0.12 & 0.02 & 0.31 & 0.05 & 0.15 & 0.02 \\
\hline $\mathrm{Al}_{2} \mathrm{O}_{3}$ & 0.20 & 0.07 & 0.04 & 0.06 & 0.04 & 0.05 & 0.04 & 0.08 & 0.02 \\
\hline $\mathrm{Fe}_{2} \mathrm{O}_{3}$ & 5.06 & 3.35 & 3.47 & 2.20 & 2.40 & 2.51 & 2.23 & 3.59 & 0.67 \\
\hline $\mathrm{FeO}$ & 2.05 & 0.77 & 0.62 & 0.86 & 0.50 & 1.67 & 1.26 & 3.02 & 0.48 \\
\hline $\mathrm{MnO}$ & 0.43 & 0.20 & 0.15 & 0.16 & 0.35 & 0.19 & 0.43 & 0.36 & 0.19 \\
\hline $\mathrm{MgO}$ & 3.32 & 2.79 & 5.21 & 2.46 & 7.48 & 4.18 & 14.38 & 12.26 & 17.90 \\
\hline $\mathrm{CaO}$ & 46.33 & 47.27 & 44.23 & 48.26 & 43.02 & 47.61 & 30.77 & 35.17 & 32.60 \\
\hline $\mathrm{Na}_{2} \mathrm{O}$ & 0.54 & 0.27 & 0.07 & 0.14 & 0.42 & 0.02 & 0.09 & 0.02 & 0.03 \\
\hline $\mathrm{K}_{2} \mathrm{O}$ & 0.04 & 0.16 & 0.09 & 0.27 & 0.03 & 0.06 & 0.04 & 0.07 & 0.01 \\
\hline $\mathrm{SrO}$ & 1.72 & 1.52 & 0.90 & 1.63 & 1.66 & 0.45 & 1.64 & 1.46 & 0.75 \\
\hline $\mathrm{BaO}$ & 1.02 & 0.27 & 0.20 & 0.25 & 0.85 & 0.53 & 4.67 & 0.54 & 0.30 \\
\hline $\mathrm{P}_{2} \mathrm{O}_{5}$ & 17.40 & 2.25 & 3.44 & 0.25 & 6.45 & 2.33 & 0.46 & 4.16 & 2.26 \\
\hline LOI-CO ${ }_{2}$ & 1.64 & 0.07 & 1.82 & 0.36 & 1.03 & 0.12 & 1.71 & 0.67 & 3.21 \\
\hline $\mathrm{CO}_{2}$ & 18.38 & 38.75 & 35.41 & 41.71 & 34.72 & 39.19 & 40.01 & 37.25 & 41.31 \\
\hline Total & 99.62 & 99.66 & 99.83 & 99.81 & 99.30 & 99.66 & 99.66 & 99.48 & 99.84 \\
\hline $\mathrm{V}$ & 101 & 48 & 42 & 22 & 19 & 68 & 13 & 44 & 12 \\
\hline $\mathrm{Cr}$ & 20 & 23 & $<20$ & $<20$ & $<20$ & 22 & $<20$ & 22 & $<20$ \\
\hline Co & 16 & 25 & 7 & 26 & 8 & 31 & 6 & 34 & 2 \\
\hline $\mathrm{Ni}$ & 31 & 33 & 24 & 29 & 21 & 53 & 16 & 35 & 15 \\
\hline $\mathrm{Cu}$ & 32 & 142 & 25 & 39 & 24 & 32 & 11 & 29 & 15 \\
\hline $\mathrm{Zn}$ & 178 & 110 & 51 & 76 & $<30$ & 151 & 61 & 96 & $<30$ \\
\hline $\mathrm{Rb}$ & 2 & 2 & 2 & 9 & $<2$ & $<2$ & $<2$ & $<2$ & $<2$ \\
\hline Y & 853 & 130 & 148 & 60.7 & 132 & 128 & 57.9 & 148 & 180 \\
\hline $\mathrm{Zr}$ & 662 & 169 & 142 & 18 & 104 & 250 & 34 & 343 & 136 \\
\hline $\mathrm{Nb}$ & 85.9 & 41.6 & 31.9 & 30.2 & 138 & 170 & 43.7 & 83.3 & 23.5 \\
\hline $\mathrm{La}$ & 432 & 585 & 348 & 548 & 2110 & 375 & 1036 & 1307 & 385 \\
\hline $\mathrm{Ce}$ & 1194 & 1303 & 781 & 1038 & 3017 & 886 & 1816 & 2581 & 776 \\
\hline $\operatorname{Pr}$ & 192 & 157 & 93.4 & 108 & 268 & 109 & 201 & 289 & 88.2 \\
\hline $\mathrm{Nd}$ & 987 & 580 & 334 & 345 & 778 & 416 & 709 & 1023 & 313 \\
\hline $\mathrm{Sm}$ & 333 & 103 & 54.7 & 44.8 & 106 & 84.2 & 122 & 151 & 58.6 \\
\hline $\mathrm{Eu}$ & 129 & 31 & 18.6 & 13.4 & 33 & 28.5 & 36.1 & 43.2 & 21.9 \\
\hline Gd & 299 & 71.6 & 49.2 & 35.5 & 89.8 & 67.1 & 82.6 & 109 & 57.1 \\
\hline $\mathrm{Tb}$ & 46.1 & 7.1 & 6.07 & 3.14 & 9.02 & 7.57 & 6.41 & 9.67 & 7.8 \\
\hline Dy & 209 & 29.1 & 30.1 & 13.3 & 35.4 & 30.9 & 19.9 & 38.3 & 39 \\
\hline Ho & 34.6 & 4.84 & 5.5 & 2.18 & 5.3 & 4.8 & 2.28 & 5.71 & 6.98 \\
\hline $\mathrm{Er}$ & 50.9 & 7.87 & 9.35 & 3.72 & 7.27 & 7.14 & 2.69 & 8.46 & 10.5 \\
\hline $\mathrm{Tm}$ & 4.37 & 0.701 & 1.07 & 0.365 & 0.47 & 0.527 & $<0.1$ & 0.54 & 0.975 \\
\hline $\mathrm{Yb}$ & 20.9 & 3.89 & 5.24 & 1.86 & 1.46 & 2.89 & $<1$ & 2.54 & 4.12 \\
\hline $\mathrm{Lu}$ & 2.77 & 0.553 & 0.499 & 0.274 & 0.204 & 0.444 & 0.111 & 0.399 & 0.55 \\
\hline $\mathrm{Hf}$ & 21.6 & 2.1 & 2.9 & 0.6 & 2.2 & 3.9 & 1.4 & 5.3 & 2.9 \\
\hline Th & 744 & 102 & 77.7 & 33.1 & 129 & 148 & 163 & 109 & 40.2 \\
\hline $\mathrm{U}$ & 28.7 & 4.05 & 3.42 & 5.09 & 4.69 & 78.6 & 1.93 & 18.5 & 3.15 \\
\hline$\Sigma$ REE & 3935 & 2885 & 1737 & 2158 & 6461 & 2020 & 4034 & 5569 & 1770 \\
\hline$(\mathrm{La} / \mathrm{Lu})_{\mathrm{n}}$ & 16 & 110 & 72 & 208 & 1074 & 88 & 969 & 340 & 73 \\
\hline
\end{tabular}


TABLE V (cont.)

\begin{tabular}{|c|c|c|c|c|c|c|c|c|}
\hline & $\begin{array}{r}10 \\
\text { BL5 }\end{array}$ & $\begin{array}{r}11 \\
\text { BO1a }\end{array}$ & $\begin{array}{r}12 \\
\text { BR1 }\end{array}$ & $\begin{array}{r}13 \\
\text { BB4 }\end{array}$ & $\begin{array}{r}14 \\
\text { BF2 }\end{array}$ & $\begin{array}{r}15 \\
\mathrm{BH} 3\end{array}$ & $\begin{array}{r}16 \\
\text { BM3 }\end{array}$ & $\begin{array}{r}17 \\
\text { BN2 }\end{array}$ \\
\hline $\mathrm{SiO}_{2}$ & 2.50 & 0.43 & 2.30 & 0.86 & 2.07 & 1.74 & 0.62 & 2.85 \\
\hline $\mathrm{TiO}_{2}$ & 0.09 & 0.03 & 0.06 & 0.03 & 0.67 & 0.07 & 0.12 & 0.99 \\
\hline $\mathrm{Al}_{2} \mathrm{O}_{3}$ & 0.09 & 0.07 & 0.06 & 0.10 & 0.05 & 0.11 & 0.09 & 0.15 \\
\hline $\mathrm{Fe}_{2} \mathrm{O}_{3}$ & 3.44 & 1.83 & 3.87 & 4.54 & 10.55 & 6.30 & 5.99 & 9.46 \\
\hline $\mathrm{FeO}$ & 2.04 & 0.56 & 0.86 & 8.40 & 0.32 & 4.99 & 5.33 & 6.06 \\
\hline $\mathrm{MnO}$ & 0.65 & 0.50 & 0.40 & 1.46 & 0.26 & 1.02 & 0.75 & 0.41 \\
\hline $\mathrm{MgO}$ & 13.62 & 10.46 & 7.48 & 11.32 & 6.41 & 11.57 & 11.01 & 7.73 \\
\hline $\mathrm{CaO}$ & 28.46 & 36.21 & 40.42 & 28.29 & 41.90 & 30.58 & 29.19 & 34.73 \\
\hline $\mathrm{Na}_{2} \mathrm{O}$ & 0.12 & 0.22 & 0.11 & & & 0.11 & 0.05 & 0.23 \\
\hline $\mathrm{K}_{2} \mathrm{O}$ & 0.14 & 0.04 & 0.26 & 0.05 & 0.23 & 0.26 & 0.06 & 0.33 \\
\hline $\mathrm{SrO}$ & 2.96 & 3.62 & 1.84 & 1.08 & 0.71 & 1.56 & 1.85 & 0.85 \\
\hline $\mathrm{BaO}$ & 3.66 & 2.27 & 2.37 & 0.96 & 0.18 & 1.42 & 2.69 & 1.34 \\
\hline $\mathrm{P}_{2} \mathrm{O}_{5}$ & 0.62 & 3.42 & 2.32 & 0.46 & 11.48 & 2.77 & 0.17 & 3.33 \\
\hline $\mathrm{LOI}-\mathrm{CO}_{2}$ & 1.97 & 0.94 & 1.91 & 1.56 & 2.58 & 1.06 & 2.32 & 0.01 \\
\hline $\mathrm{CO}_{2}$ & 38.18 & 37.78 & 34.84 & 39.95 & 22.33 & 35.56 & 38.94 & 31.26 \\
\hline Total & 98.54 & 99.38 & 99.10 & 99.06 & 99.74 & 99.12 & 99.18 & 99.73 \\
\hline $\mathrm{V}$ & 36 & 21 & 40 & 29 & 122 & 45 & 49 & 153 \\
\hline $\mathrm{Cr}$ & 22 & $<20$ & $<20$ & 40 & 457 & 58 & 88 & 33 \\
\hline Co & 15 & 3 & 30 & 6 & 19 & 31 & 19 & 62 \\
\hline $\mathrm{Ni}$ & 29 & $<15$ & 24 & 18 & 2070 & 38 & 224 & 72 \\
\hline $\mathrm{Cu}$ & 15 & 16 & 49 & 12 & 34 & 21 & 13 & 360 \\
\hline $\mathrm{Zn}$ & 225 & 48 & 691 & 60 & 79 & 103 & 646 & 268 \\
\hline $\mathrm{Rb}$ & 6 & $<2$ & 6 & $<2$ & 10 & 10 & 2 & 11 \\
\hline $\mathrm{Y}$ & 28 & 95.2 & 69.4 & 13.6 & 259 & 38.3 & 53.1 & 186 \\
\hline $\mathrm{Zr}$ & 28 & 114 & 94 & 11 & 245 & 36 & 19 & 134 \\
\hline $\mathrm{Nb}$ & 379 & 55.1 & 118 & 40.9 & 104 & 22.5 & 259 & 84 \\
\hline $\mathrm{La}$ & 4619 & 6454 & 2814 & 2302 & 475 & 2001 & 2456 & 409 \\
\hline $\mathrm{Ce}$ & 5848 & 8007 & 3978 & 5104 & 1071 & 4536 & 4175 & 919 \\
\hline $\operatorname{Pr}$ & 440 & 627 & 324 & 570 & 139 & 479 & 409 & 118 \\
\hline $\mathrm{Nd}$ & 1072 & 1526 & 881 & 1707 & 525 & 1652 & 1335 & 474 \\
\hline $\mathrm{Sm}$ & 68.9 & 115 & 83 & 150 & 84.3 & 155 & 218 & 99.9 \\
\hline $\mathrm{Eu}$ & 15.1 & 28.3 & 21.7 & 29.7 & 27.1 & 33 & 66.3 & 32.5 \\
\hline $\mathrm{Gd}$ & 62.3 & 104 & 63.7 & 93.7 & 70 & 85.5 & 146 & 74.5 \\
\hline $\mathrm{Tb}$ & 3.36 & 7.97 & 4.8 & 3.37 & 9.81 & 4.27 & 11.3 & 9.99 \\
\hline Dy & 7.95 & 26.5 & 16.3 & 5.44 & 52.6 & 12.3 & 27.2 & 48 \\
\hline Ho & 1.02 & 3.86 & 2.47 & 0.23 & 10.2 & 1.3 & 2.22 & 7.71 \\
\hline $\mathrm{Er}$ & 1.59 & 5.77 & 3.77 & 0.11 & 20.6 & 1.47 & 2.03 & 11.2 \\
\hline $\mathrm{Tm}$ & 0.074 & 0.357 & 0.244 & $<0.1$ & 3.24 & $<0.2$ & $<0.1$ & 0.905 \\
\hline $\mathrm{Yb}$ & $<2$ & $<2$ & $<2$ & $<1$ & 19.2 & $<1$ & $<1$ & 4.27 \\
\hline $\mathrm{Lu}$ & 0.336 & 0.269 & 0.084 & 0.003 & 2.265 & 0.047 & 0.083 & 0.576 \\
\hline Hf & 1 & 2.6 & 2 & 0.6 & 5.6 & 0.9 & 1.3 & 2.2 \\
\hline Th & 76.4 & 129 & 58.6 & 111 & 164 & 45.5 & 594 & 153 \\
\hline $\mathrm{U}$ & 1.15 & 11.2 & 36.5 & 12.6 & 9.19 & 1.67 & 6.83 & 5.58 \\
\hline$\Sigma$ REE & 12140 & 16906 & 8193 & 9966 & 2509 & 8961 & 8848 & 2210 \\
\hline$(\mathrm{La} / \mathrm{Lu})_{\mathrm{n}}$ & 1428 & 2492 & 3480 & 79704 & 22 & 4422 & 3074 & 74 \\
\hline
\end{tabular}

numbers listed in literature (cf. Woolley \& Kempe 1989): 127 vs. 1204 ppm for $\mathrm{CaC}, 334$ vs. 569 ppm for $\mathrm{MgC}$ and 194 vs. $1292 \mathrm{ppm}$ for FeC.
$\mathrm{Sr}$ is variably enriched in Araxá carbonatites, the larger amounts being found in the $\mathrm{MgC}$ group, as also suggested by the occurrence of strontianite. $\mathrm{Ba}$ 


\section{TABLE VI}

Representative bulk-chemical analyses of Araxá mica-rich rocks (1-12, G; 13-20, MOP; 21-24, MC). For rock abbreviations see Table I. Major and trace elements in wt\% and ppm, respectively.

\begin{tabular}{|c|c|c|c|c|c|c|c|c|}
\hline & 1 & 2 & 3 & 4 & 5 & 6 & 7 & 8 \\
\hline & BD1 & BG3 & BI6 & $\mathrm{BN} 4$ & $\mathrm{BO} 4 \mathrm{~b}$ & BQ3 & BT1 & BT3 \\
\hline $\mathrm{SiO}_{2}$ & 24.03 & 25.69 & 16.79 & 19.68 & 21.31 & 35.50 & 23.13 & 20.81 \\
\hline $\mathrm{TiO}_{2}$ & 3.36 & 2.74 & 2.45 & 1.87 & 2.73 & 1.82 & 2.30 & 4.07 \\
\hline $\mathrm{Al}_{2} \mathrm{O}_{3}$ & 1.68 & 1.12 & 1.90 & 1.43 & 2.07 & 6.52 & 3.38 & 0.09 \\
\hline $\mathrm{Fe}_{2} \mathrm{O}_{3}$ & 10.69 & 6.28 & 20.12 & 6.88 & 10.17 & 7.27 & 11.49 & 26.57 \\
\hline $\mathrm{FeO}$ & 3.95 & 3.30 & 9.15 & 2.94 & 3.09 & 2.66 & 5.31 & 12.14 \\
\hline $\mathrm{MnO}$ & 0.33 & 0.37 & 0.41 & 0.28 & 0.29 & 0.17 & 0.35 & 0.81 \\
\hline $\mathrm{MgO}$ & 17.71 & 15.77 & 13.63 & 18.09 & 17.80 & 21.26 & 11.75 & 14.52 \\
\hline $\mathrm{CaO}$ & 12.76 & 14.93 & 15.29 & 18.70 & 14.76 & 5.78 & 18.27 & 2.88 \\
\hline $\mathrm{Na}_{2} \mathrm{O}$ & & 0.13 & & 0.14 & & & 0.61 & 0.13 \\
\hline $\mathrm{K}_{2} \mathrm{O}$ & 5.20 & 2.84 & 2.94 & 3.48 & 4.42 & 6.99 & 4.34 & 3.24 \\
\hline $\mathrm{SrO}$ & 0.39 & 0.54 & 0.24 & 0.44 & 0.75 & 0.46 & 0.62 & 0.06 \\
\hline $\mathrm{BaO}$ & 0.27 & 0.38 & 0.12 & 0.35 & 0.58 & 0.18 & 0.48 & 0.24 \\
\hline $\mathrm{P}_{2} \mathrm{O}_{5}$ & 1.03 & 0.28 & 2.41 & 1.09 & 1.52 & 0.13 & 7.71 & 0.10 \\
\hline $\mathrm{LOI}-\mathrm{CO}_{2}$ & 2.42 & 2.56 & 4.58 & 3.03 & 2.31 & 4.25 & 2.22 & 1.54 \\
\hline $\mathrm{CO}_{2}$ & 15.56 & 22.67 & 9.42 & 21.00 & 17.69 & 6.08 & 7.46 & 12.70 \\
\hline Total & 99.38 & 99.60 & 99.45 & 99.40 & 99.49 & 99.07 & 99.42 & 99.90 \\
\hline V & 88 & 152 & 929 & 176 & 111 & 127 & 211 & 1071 \\
\hline $\mathrm{Cr}$ & 576 & 178 & $<20$ & 816 & 369 & 174 & $<20$ & 26 \\
\hline Co & 53 & 39 & 59 & 54 & 51 & 27 & 51 & 65 \\
\hline $\mathrm{Ni}$ & 393 & 106 & 76 & 526 & 147 & 69 & 42 & $<15$ \\
\hline $\mathrm{Cu}$ & 31 & 15 & 68 & 50 & 57 & 21 & 201 & $<10$ \\
\hline $\mathrm{Zn}$ & 222 & 122 & 327 & 84 & 132 & 81 & 230 & 579 \\
\hline $\mathrm{Rb}$ & 145 & 91 & 106 & 104 & 164 & 273 & 135 & 78 \\
\hline Y & 35.5 & 41.1 & 64.1 & 59.4 & 31.6 & 51 & 205 & 14.8 \\
\hline $\mathrm{Zr}$ & 1019 & 280 & 421 & 666 & 958 & 2909 & 2900 & 176 \\
\hline $\mathrm{Nb}$ & 286 & 497 & 152 & 161 & 861 & 1792 & 539 & 183 \\
\hline $\mathrm{La}$ & 1070 & 703 & 184 & 724 & 377 & 158 & 573 & 44.5 \\
\hline $\mathrm{Ce}$ & 1822 & 1509 & 492 & 1189 & 817 & 475 & 1290 & 92.1 \\
\hline $\operatorname{Pr}$ & 168 & 166 & 63.25 & 114 & 87 & 59.8 & 146 & 10 \\
\hline $\mathrm{Nd}$ & 503 & 577 & 255 & 365 & 292 & 244 & 532 & 35.8 \\
\hline $\mathrm{Sm}$ & 50.2 & 76.8 & 47.9 & 47.9 & 37.1 & 47.2 & 95.4 & 5.8 \\
\hline $\mathrm{Eu}$ & 12.2 & 19.7 & 14.7 & 13.4 & 9.92 & 14.5 & 31.6 & 1.71 \\
\hline $\mathrm{Gd}$ & 31.9 & 43.6 & 32.1 & 32.2 & 23.6 & 29.7 & 77.7 & 4.17 \\
\hline $\mathrm{Tb}$ & 2.43 & 3.19 & 3.89 & 3.31 & 2.19 & 3.8 & 10.5 & 0.57 \\
\hline Dy & 9.34 & 11.4 & 18.6 & 15 & 9.48 & 17.8 & 49.6 & 3.05 \\
\hline Ho & 1.37 & 1.53 & 3.15 & 2.46 & 1.48 & 2.86 & 8.23 & 0.6 \\
\hline $\mathrm{Er}$ & 2.03 & 2.7 & 5.3 & 3.8 & 2.18 & 4.65 & 12.7 & 1.13 \\
\hline $\mathrm{Tm}$ & 0.168 & 0.29 & 0.576 & 0.334 & 0.159 & 0.482 & 1.23 & 0.158 \\
\hline $\mathrm{Yb}$ & 0.42 & 1.37 & 3.04 & 1.47 & 0.71 & 2.46 & 5.89 & 0.82 \\
\hline $\mathrm{Lu}$ & 0.045 & 0.188 & 0.345 & 0.189 & 0.095 & 0.237 & 0.564 & 0.086 \\
\hline Hf & 28 & 7.3 & 9.2 & 12 & 21.4 & 65 & 48.3 & 3.5 \\
\hline Th & 42.3 & 75.5 & 192 & 68.8 & 142 & 481 & 117 & 24.8 \\
\hline $\mathrm{U}$ & 4.09 & 12.3 & 80.9 & 9.16 & 21.3 & 440 & 15.2 & 4.38 \\
\hline$\Sigma \mathrm{REE}$ & 3673 & 3116 & 1124 & 2512 & 1660 & 1060 & 2834 & 200 \\
\hline$(\mathrm{La} / \mathrm{Lu})_{\mathrm{n}}$ & 2470 & 388.4 & 55.4 & 397.9 & 412.2 & 69.25 & 105.5 & 53.75 \\
\hline
\end{tabular}


TABLE VI (cont.)

\begin{tabular}{|c|c|c|c|c|c|c|c|c|}
\hline & 9 & 10 & 11 & 12 & 13 & 14 & 15 & 16 \\
\hline & BT6 & BU4 & BY5 & BAC2 & BM5 & BS2 & BS3 & BZ1 \\
\hline $\mathrm{SiO}_{2}$ & 23.87 & 17.56 & 32.12 & 14.31 & 31.56 & 30.41 & 24.41 & 25.67 \\
\hline $\mathrm{TiO}_{2}$ & 2.84 & 2.42 & 3.41 & 1.14 & 3.53 & 2.14 & 3.02 & 4.59 \\
\hline $\mathrm{Al}_{2} \mathrm{O}_{3}$ & 2.51 & 2.36 & 2.33 & 1.70 & 2.15 & 2.83 & 3.03 & 3.23 \\
\hline $\mathrm{Fe}_{2} \mathrm{O}_{3}$ & 9.02 & 7.38 & 8.35 & 8.26 & 9.83 & 1.76 & 8.55 & 10.43 \\
\hline $\mathrm{FeO}$ & 5.11 & 3.04 & 3.34 & 4.37 & 4.28 & 8.17 & 6.09 & 4.29 \\
\hline $\mathrm{MnO}$ & 0.49 & 0.27 & 0.20 & 0.27 & 0.35 & 0.30 & 0.44 & 0.25 \\
\hline $\mathrm{MgO}$ & 20.84 & 13.76 & 13.05 & 10.25 & 17.51 & 12.59 & 12.85 & 14.90 \\
\hline $\mathrm{CaO}$ & 8.12 & 21.47 & 13.25 & 28.87 & 9.79 & 21.81 & 18.31 & 16.42 \\
\hline $\mathrm{Na}_{2} \mathrm{O}$ & 0.14 & 0.20 & 0.12 & & 0.66 & 0.76 & 0.26 & 0.19 \\
\hline $\mathrm{K}_{2} \mathrm{O}$ & 4.27 & 3.27 & 3.34 & 2.85 & 4.82 & 3.08 & 3.10 & 3.81 \\
\hline $\mathrm{SrO}$ & 0.16 & 0.52 & 0.16 & 0.73 & 0.15 & 0.41 & 0.41 & 0.27 \\
\hline $\mathrm{BaO}$ & 0.38 & 0.32 & 0.31 & 0.26 & 0.16 & 0.22 & 0.61 & 0.24 \\
\hline $\mathrm{P}_{2} \mathrm{O}_{5}$ & 0.29 & 2.82 & 0.94 & 8.67 & 2.72 & 8.89 & 5.81 & 3.27 \\
\hline LOI-CO ${ }_{2}$ & 2.04 & 1.99 & 2.08 & 2.36 & 2.31 & 2.31 & 1.70 & 1.93 \\
\hline $\mathrm{CO}_{2}$ & 19.66 & 22.18 & 16.68 & 15.20 & 9.69 & 3.46 & 10.82 & 9.92 \\
\hline Total & 99.74 & 99.56 & 99.68 & 99.24 & 99.51 & 99.14 & 99.41 & 99.41 \\
\hline $\mathrm{V}$ & 175 & 148 & 255 & 131 & 196 & 236 & 196 & 141 \\
\hline $\mathrm{Cr}$ & 590 & 315 & 916 & 153 & 819 & 67 & 160 & 490 \\
\hline Co & 39 & 38 & 116 & 40 & 62 & 29 & 36 & 78 \\
\hline $\mathrm{Ni}$ & 169 & 181 & 445 & 127 & 571 & 135 & 181 & 212 \\
\hline $\mathrm{Cu}$ & $<10$ & 61 & 18 & 58 & 126 & 225 & 689 & 102 \\
\hline $\mathrm{Zn}$ & 305 & 125 & 102 & 114 & 136 & 105 & 119 & 91 \\
\hline $\mathrm{Rb}$ & 158 & 126 & 105 & 105 & 142 & 84 & 110 & 121 \\
\hline $\mathrm{Y}$ & 13.2 & 47.6 & 38.9 & 210 & 47.4 & 160 & 85.6 & 83.7 \\
\hline $\mathrm{Zr}$ & 386 & 426 & 148 & 1421 & 182 & 112 & 391 & 711 \\
\hline $\mathrm{Nb}$ & 421 & 419 & 138 & 312 & 339 & 78.4 & 206 & 254 \\
\hline $\mathrm{La}$ & 80 & 540 & 219 & 458 & 314 & 426 & 825 & 511 \\
\hline $\mathrm{Ce}$ & 184 & 1265 & 425 & 1085 & 653 & 823 & 1653 & 1078 \\
\hline $\operatorname{Pr}$ & 19.8 & 144 & 45.7 & 134 & 71.1 & 93.2 & 179 & 118 \\
\hline $\mathrm{Nd}$ & 65.4 & 508 & 163 & 527 & 248 & 337 & 593 & 419 \\
\hline $\mathrm{Sm}$ & 8.17 & 68 & 27.1 & 104 & 38.1 & 59.9 & 71.9 & 65.3 \\
\hline $\mathrm{Eu}$ & 2.21 & 17.1 & 8.7 & 32.5 & 11.2 & 20.1 & 19.6 & 19.4 \\
\hline $\mathrm{Gd}$ & 5.73 & 40.9 & 21.2 & 76.5 & 26.2 & 51.8 & 50.3 & 45.7 \\
\hline $\mathrm{Tb}$ & 0.62 & 3.27 & 2.33 & 10.9 & 3.06 & 7.17 & 4.77 & 5 \\
\hline Dy & 2.84 & 12.4 & 9.71 & 54.4 & 13.1 & 36.3 & 21 & 21.9 \\
\hline Ho & 0.48 & 1.79 & 1.53 & 9.04 & 2.07 & 6.52 & 3.38 & 3.54 \\
\hline $\mathrm{Er}$ & 0.88 & 2.57 & 2.51 & 13 & 3.04 & 10.7 & 5.58 & 5.48 \\
\hline $\mathrm{Tm}$ & 0.114 & 0.138 & 0.222 & 1.06 & 0.253 & 1.16 & 0.499 & 0.485 \\
\hline $\mathrm{Yb}$ & 0.66 & 0.67 & 1.34 & 4.5 & 1.29 & 5.42 & 1.94 & 2.19 \\
\hline $\mathrm{Lu}$ & 0.066 & 0.084 & 0.122 & 0.523 & 0.181 & 0.553 & 0.257 & 0.265 \\
\hline $\mathrm{Hf}$ & 8.2 & 5.7 & 3.9 & 37.2 & 3.7 & 2.6 & 7.8 & 16.3 \\
\hline Th & 23.3 & 50.9 & 67.3 & 166 & 56.1 & 76.6 & 69.7 & 61.1 \\
\hline $\mathrm{U}$ & 12.7 & 6.06 & 2.45 & 82.2 & 9.08 & 13.1 & 15.2 & 12.1 \\
\hline$\Sigma$ REE & 371 & 2604 & 927 & 2510 & 1385 & 1879 & 3429 & 2295 \\
\hline$(\mathrm{La} / \mathrm{Lu})_{\mathrm{n}}$ & 125.9 & 667.74 & 186.5 & 90.96 & 180.2 & 80.02 & 333.4 & 200.3 \\
\hline
\end{tabular}

shows similar contents relative to the Woolley and Kempe (1989) numbers for $\mathrm{CaC}$ and $\mathrm{FeC}$ groups and is strongly enriched in $\mathrm{MgC}$. These rocks also bear the highest values in L.O.I- $\mathrm{CO}_{2}$ (Table V), probably associated to the presence of $\mathrm{SO}_{3}$. In most of the alkaline-carbonatite complexes (cf. Woolley \& 
TABLE VI (cont.)

\begin{tabular}{|c|c|c|c|c|c|c|c|c|}
\hline & $\begin{array}{r}17 \\
\mathrm{BZ2}\end{array}$ & $\begin{array}{r}18 \\
\text { BAB2 }\end{array}$ & $\begin{array}{r}19 \\
\text { BAC } 1\end{array}$ & $\begin{array}{r}20 \\
\text { BAR8 }\end{array}$ & $\begin{array}{r}21 \\
\mathrm{BG} 1\end{array}$ & $\begin{array}{r}22 \\
\text { BL2 }\end{array}$ & $\begin{array}{r}23 \\
\text { BL8 }\end{array}$ & $\begin{array}{r}24 \\
\text { BL9 }\end{array}$ \\
\hline $\mathrm{SiO}_{2}$ & 27.82 & 18.47 & 19.13 & 32.85 & 25.02 & 18.55 & 24.18 & 18.70 \\
\hline $\mathrm{TiO}_{2}$ & 3.81 & 2.36 & 3.62 & 5.05 & 4.93 & 2.57 & 3.44 & 2.19 \\
\hline $\mathrm{Al}_{2} \mathrm{O}_{3}$ & 2.58 & 2.01 & 1.82 & 3.52 & 5.76 & 1.84 & 2.70 & 1.99 \\
\hline $\mathrm{Fe}_{2} \mathrm{O}_{3}$ & 9.99 & 13.40 & 7.63 & 9.12 & 9.52 & 9.02 & 8.81 & 7.54 \\
\hline $\mathrm{FeO}$ & 3.72 & 4.68 & 4.73 & 4.64 & 7.43 & 4.14 & 5.20 & 5.51 \\
\hline $\mathrm{MnO}$ & 0.32 & 0.36 & 0.24 & 0.21 & 0.30 & 0.37 & 0.41 & 0.55 \\
\hline $\mathrm{MgO}$ & 15.40 & 12.90 & 8.05 & 16.36 & 16.17 & 13.31 & 19.20 & 16.83 \\
\hline $\mathrm{CaO}$ & 15.00 & 23.33 & 30.60 & 16.41 & 10.19 & 21.14 & 11.38 & 16.24 \\
\hline $\mathrm{Na}_{2} \mathrm{O}$ & 0.44 & 0.05 & 0.08 & 0.26 & 0.17 & 0.22 & 0.01 & 0.06 \\
\hline $\mathrm{K}_{2} \mathrm{O}$ & 4.18 & 3.79 & 2.60 & 3.95 & 5.24 & 3.88 & 5.13 & 3.95 \\
\hline $\mathrm{SrO}$ & 0.49 & 0.42 & 0.48 & 0.17 & 0.42 & 0.82 & 0.84 & 1.03 \\
\hline $\mathrm{BaO}$ & 0.38 & 0.21 & 0.15 & 0.25 & 0.85 & 0.53 & 0.28 & 0.38 \\
\hline $\mathrm{P}_{2} \mathrm{O}_{5}$ & 4.84 & 4.91 & 4.16 & 1.02 & 3.12 & 6.00 & 1.05 & 0.36 \\
\hline $\mathrm{LOI}-\mathrm{CO}_{2}$ & 2.22 & 1.79 & 1.31 & 1.76 & 3.05 & 2.03 & 2.23 & 1.96 \\
\hline $\mathrm{CO}_{2}$ & 7.88 & 11.03 & 15.08 & 4.00 & 7.36 & 14.75 & 14.42 & 21.87 \\
\hline Total & 99.07 & 99.71 & 99.68 & 99.57 & 99.53 & 99.17 & 99.28 & 99.16 \\
\hline V & 173 & 182 & 273 & 198 & 152 & 132 & 82 & 36 \\
\hline $\mathrm{Cr}$ & 533 & 34 & 156 & 745 & 260 & 234 & 486 & 374 \\
\hline Co & 87 & 60 & 59 & 65 & 49 & 45 & 51 & 52 \\
\hline $\mathrm{Ni}$ & 279 & 198 & 132 & 394 & 115 & 146 & 302 & 286 \\
\hline $\mathrm{Cu}$ & 173 & 81 & 108 & 53 & 26 & 66 & 30 & 48 \\
\hline $\mathrm{Zn}$ & 186 & 227 & 114 & 104 & 174 & 329 & 183 & 129 \\
\hline $\mathrm{Rb}$ & 136 & 120 & 76 & 108 & 155 & 101 & 161 & 124 \\
\hline $\mathrm{Y}$ & 133 & 125 & 65.5 & 48.2 & 84 & 158 & 31 & 10 \\
\hline $\mathrm{Zr}$ & 283 & 345 & 183 & 631 & 385 & 302 & 699 & 446 \\
\hline $\mathrm{Nb}$ & 127 & 236 & 162 & 286 & 486 & 558 & 774 & 254 \\
\hline $\mathrm{La}$ & 476 & 555 & 447 & 469 & 1032 & 2150 & 1617 & 2102 \\
\hline $\mathrm{Ce}$ & 1131 & 1202 & 923 & 960 & 1933 & 3631 & 2459 & 3040 \\
\hline $\operatorname{Pr}$ & 136 & 139 & 98.7 & 101 & 202 & 329 & 218 & 255 \\
\hline $\mathrm{Nd}$ & 497 & 511 & 333 & 346 & 681 & 963 & 627 & 684 \\
\hline $\mathrm{Sm}$ & 80.9 & 80.4 & 45.9 & 48.8 & 93.2 & 91.5 & 59.3 & 50.8 \\
\hline $\mathrm{Eu}$ & 24.7 & 23.9 & 13.5 & 13.9 & 26 & 23.2 & 14.2 & 10 \\
\hline $\mathrm{Gd}$ & 57.7 & 57.9 & 34.7 & 32.8 & 62.4 & 66.1 & 38.2 & 27.1 \\
\hline $\mathrm{Tb}$ & 6.62 & 6.38 & 3.88 & 3.33 & 5.84 & 6.63 & 2.61 & 1.28 \\
\hline Dy & 30.7 & 28.3 & 17.2 & 14.2 & 23.3 & 33.2 & 8.7 & 3.07 \\
\hline Ho & 5.19 & 4.76 & 2.67 & 2.19 & 3.36 & 6.13 & 1.17 & 0.33 \\
\hline $\mathrm{Er}$ & 9 & 7.93 & 3.94 & 3.46 & 4.97 & 10.3 & 1.66 & 0.42 \\
\hline $\mathrm{Tm}$ & 1 & 0.765 & 0.363 & 0.276 & 0.329 & 1.18 & $<0.1$ & $<0.1$ \\
\hline $\mathrm{Yb}$ & 5.46 & 4.04 & 1.68 & 1.17 & 1.41 & 4.6 & $<1$ & $<1$ \\
\hline $\mathrm{Lu}$ & 0.641 & 0.614 & 0.228 & 0.125 & 0.178 & 0.625 & 0.041 & 0.022 \\
\hline Hf & 7.9 & 8.4 & 3.7 & 15.3 & 8.8 & 5 & 13.5 & 8.1 \\
\hline Th & 82.7 & 76.7 & 55.2 & 41.3 & 73 & 89.4 & 41.4 & 18.7 \\
\hline $\mathrm{U}$ & 17.2 & 14.3 & 26.3 & 16.5 & 10.9 & 16.3 & 16.1 & 2.13 \\
\hline$\Sigma$ REE & 2462 & 2622 & 1926 & 1996 & 4069 & 7316 & 5047 & 6174 \\
\hline$(\mathrm{La} / \mathrm{Lu})_{\mathrm{n}}$ & 77.13 & 93.89 & 203.6 & 389.7 & 602.2 & 357.3 & 4097 & 9924 \\
\hline
\end{tabular}

Kempe 1989), Sr and Ba reach higher concentrations in $\mathrm{FeC}$.
$\mathrm{MgC}$ and $\mathrm{FeC}, \Sigma \mathrm{REE}$ vary within the intervals 1736-6460 ppm, 1769-16906 ppm and 2204-9965

$\mathrm{MgC}$ rocks are also enriched in $\mathrm{REE}$. For $\mathrm{CaC}, \quad \mathrm{ppm}$, respectively (Table $\mathrm{V}$ ). 

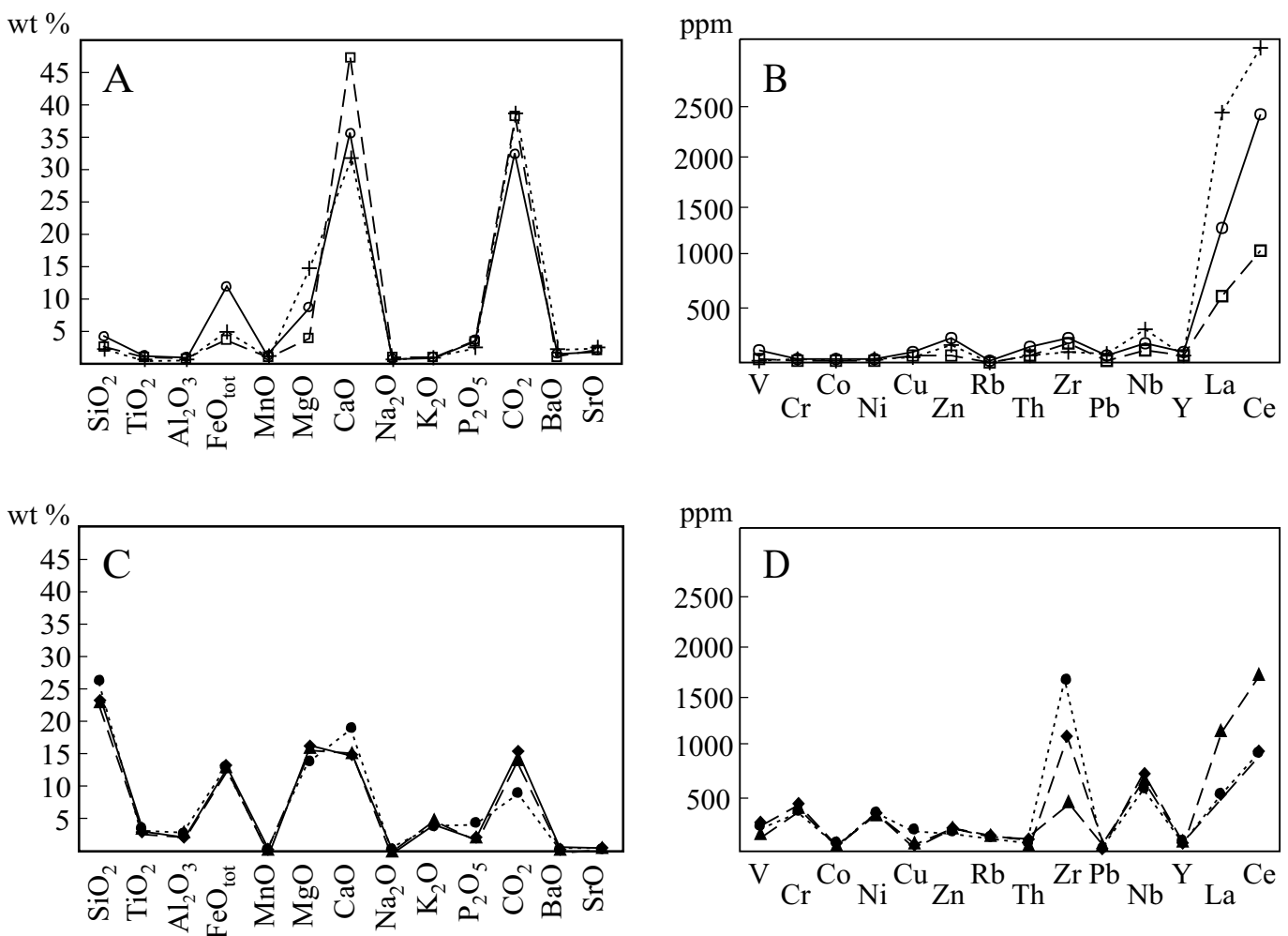

Fig. 6-Average composition of carbonatites (A and B) and mica-rich rocks (C and D) from Araxá. Symbols: empty square, $\mathrm{CaC}$; cross, $\mathrm{MgC}$; empty circle, $\mathrm{FeC}$; full diamond, G; full circle, MOP; full triangle, MC.

As previously mentioned, the mica-rich rocks, here included the hybrid lithotypes, are uniform in composition, independently of mica being either a primary or a secondary phase (Fig. 6). The most significant differences deal with the proportion of carbonate minerals, these mainly represented by dolomite, as indicated by the negative correlation $\mathrm{CO}_{2}-\mathrm{CaO}$. In MOP rocks, $\mathrm{CaO}$ is mostly associated to clinopyroxenes. $\mathrm{CO}_{2}$ content varies within the three rock-types, the average values being 9\%, 14\% and $15.5 \%$ for MOP, MC and G, respectively.

$\mathrm{Nb}$ is strongly enriched in all three groups, with mean values (718 ppm, G; 668 ppm, MC; 571 ppm, MOP) considerably higher in relation to those of the carbonatites $(\mathrm{MgC}$ presents the highest average concentration, $334 \mathrm{ppm}$ ).

$\mathrm{La} / \mathrm{Ce}$ ratios are almost constant for carbonatites, mica-rich rocks and hybrid lithotypes. $\mathrm{G}$ and
MOP samples are particularly enriched in $\mathrm{Zr}$ and glimmeritic rocks contain high $\mathrm{Nb}$ contents.

Chondrite-normalized (cf. Boynton 1984) REE patterns for Araxá rocks are illustrated in Fig. 9. All the rock-types are strongly enriched in REE, the highest values found in some $\mathrm{MgC}$ samples. Steep LREE/HREE fractionation characterizes the three groups, as clearly pointed by the $(\mathrm{La} / \mathrm{Lu})_{\mathrm{n}} \mathrm{ra}-$ tios listed in Tables V and VI, reaching up to 79704 in a $\mathrm{MgC}$ sample (BB4, an. 13, Table V).

The convex behaviour of the $\mathrm{CaC}$ sample $\mathrm{BB} 3$ (Fig. 9) with MREE values higher than those obtained for LREE, and also showing Y content of 853 ppm (average value for $\mathrm{CaC}=68 \mathrm{ppm}$ ), may be related to the presence of supergenic monazite.

$\mathrm{MC}$ and $\mathrm{FeC}$ rocks behave similarly to some samples presenting less enrichment in MREE and HREE; the reason is probably associated to 

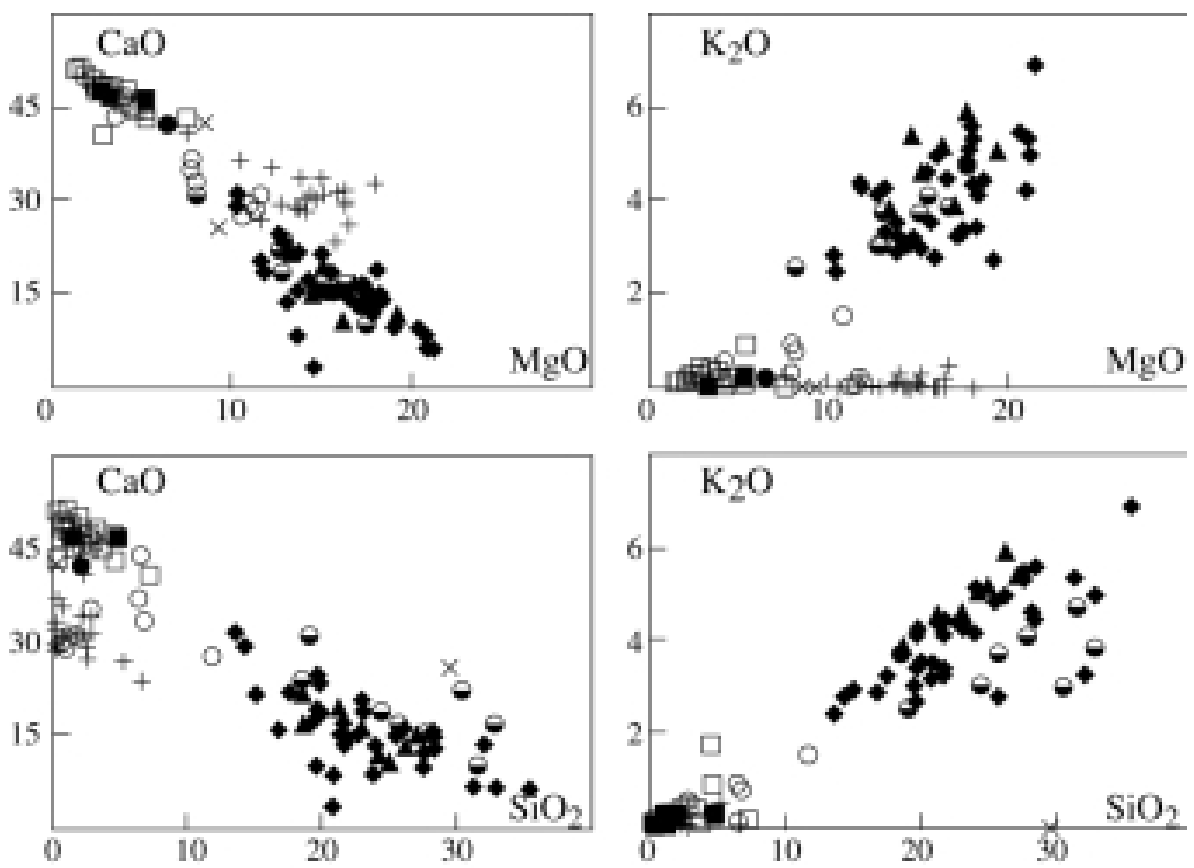

Fig. $7-\mathrm{CaO}$ and $\mathrm{K}_{2} \mathrm{O}$ vs. $\mathrm{MgO}$ and $\mathrm{CaO}$ and $\mathrm{K}_{2} \mathrm{O}$ vs. $\mathrm{SiO}_{2}$ diagrams (wt\%) for carbonatites and mica-rich rocks from Araxá. Symbols as in Fig. 5.

pyrochlore, which, according to Hornig-Kjarsgaard (1998), can be impoverished in HREE.

REE distribution in MOP rocks is very uniform and characterized by slight LREE/HREE fractionation, the maximum $(\mathrm{La} / \mathrm{Lu})_{\mathrm{n}}$ value being 389.7 (an. 20, Table VI). The regular behaviour of REE is indicative that garnet (melanitic or kimzeyitic in composition) has not played an important role in the fractionation process.

$\mathrm{G}$ rocks exhibit an irregular pattern with variable enrichment degree for LREE (La and Ce values ranging from 100 up to 3000 times chondrite) and also variable LREE/HREE fractionation.

\section{CONCLUDING REMARKS}

The investigated rocks cover a small area of the central-western portion of the Araxá complex. In addition to a few surface samples, they consist mainly of borehole material taken from 28 wells normally not deeper than $100 \mathrm{~m}$. In spite of sampling limitation, the rocks are considered to be representative of the whole complex as they correspond to the principal lithologies present.

Two main lithotypes are recognized: carbonatites - ranging in composition from calcio-, magnesio- to ferro-types - and mica-rich rocks. Subordinately, a third petrographic variety of hybrid composition (silicate and carbonate material) is also found.

Magnesiocarbonatites $(\mathrm{MgC})$ and calciocarbonatites $(\mathrm{CaC})$ are widespread and represented by coarse- and fine-grained varieties, the latter forming dykes and small veins. Petrographically, they can be referred to as sovite-alvikite and beforsiterauhaugite, respectively. In minor amounts, ferrocarbonatites $(\mathrm{FeC})$ are also present, the iron enrichment as a result of the presence of $\mathrm{Fe}$-carbonates and opaques as cumulus phases.

Carbonate minerals correspond to at least $80 \%$ of the whole composition of the rocks. In $\mathrm{CaC}$ rocks, calcite having low $\mathrm{MgO}$ and high $\mathrm{SrO}$ is the dominant carbonate phase, whereas dolomite makes up the main constituent in $\mathrm{MgC}$ and $\mathrm{FeC}$ types. 

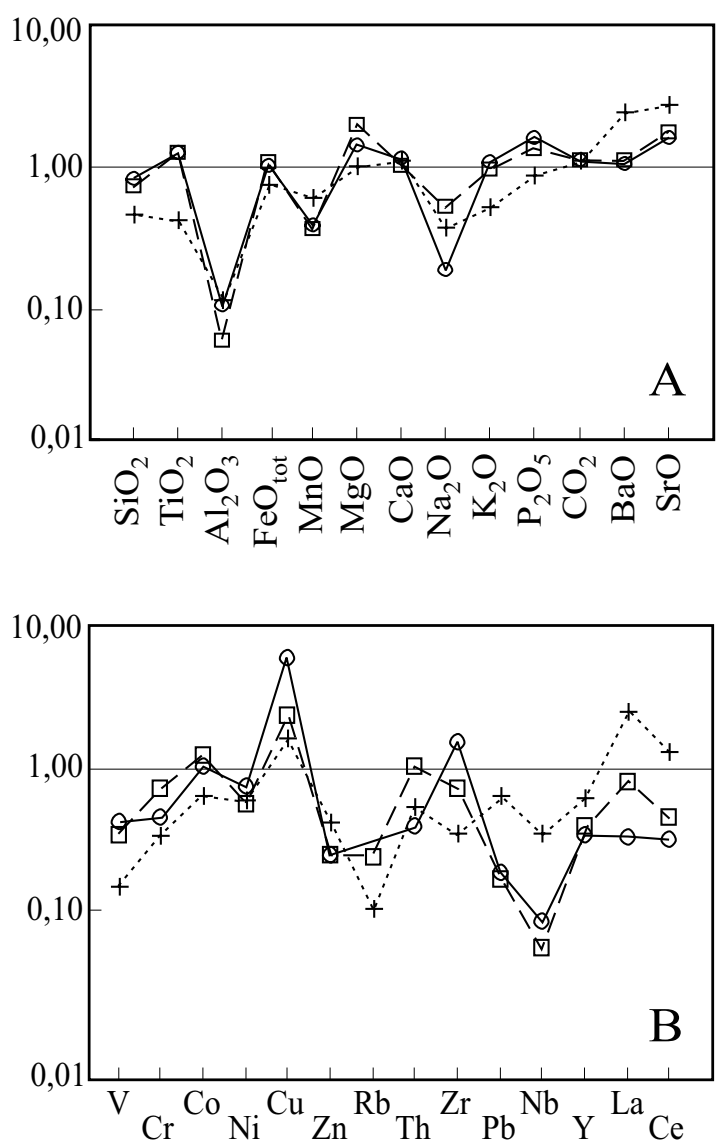

Fig. 8-Average major (A) and trace element (B) compositions of calciocarbonatites, magnesiocarbonatites and ferrocarbonatites from Araxá normalized to the respective average values according to Woolley and Kempe (1989). Symbols as in Fig. 6.

Other carbonate phases are ankerite, siderite, strontianite and magnesite, the last two minerals only found in the $\mathrm{MgC}$ group. REE carbonates (Cegroup Rare Earth minerals: huanghoite; baritocalcite and norsethite) as primary or secondary phases are also present. Silicate minerals, well represented in MOP rocks showing no evidences of metasomatism, are magnesian olivine, diopside, phlogopite and tetraferriphlogopite. The accessory assemblage includes a variable number of minerals, the most diffuse ones being phosphates (apatite and monazite) and oxides (pyrochlore, rutile and magnetite). Magnesioarfvedsonite and antophyllite are secondary phases formed after the transformation of clinopyroxene and olivine crystals, respectively. Other common phases are celadonite, as alteration product of mafic minerals, quartz and baryte.

The carbonatitic rocks strongly enriched in apatite, phlogopite, magnetite and olivine pseudomorphs may be grouped into the phoscorites of Issa Filho et al. (1984).

The mica-rich rocks are represented by scarce, not completely transformed cumulitic pyroxenites (MOP) having phlogopite, olivine and diopside as principal cumulus phases. The most abundant lithotype of the group consists of glimmeritic rocks $(\mathrm{G})$ where secondary micaceous aggregates were formed as a result of the pyroxenite modification. The original cumulitic nature of the pyroxenitic rocks is still preserved in some samples. The hybrid rocks (MC), occurring subordinately to the previous ones, are mainly composed of phlogopite cumulus having apatite, perovskite and magnetite grains as inclusions and of tetraferriphlogopite as intercumulus phase. Carbonate minerals (calcite and dolomite) are also found in association with the mica. These hybrid rocks are clearly intercepted by abundant minute veins of carbonatitic composition.

Average compositions for carbonatitic (63 analyses) and mica-rich rocks, here included the hybrid lithotypes (51 analyses), are shown in Fig. 10. Excluding phoscoritic and quartz-baryte-enriched rocks, the distribution of trace elements indicates that the carbonatites contain smaller amounts of $\mathrm{V}$, $\mathrm{Cr}, \mathrm{Ni}, \mathrm{Rb}, \mathrm{Zr}$ and $\mathrm{Nb}$ relative to the mica-rich rocks, but are highly enriched in $\mathrm{La}$ and $\mathrm{Ce}$. No significant variations are presented by $\mathrm{Co}, \mathrm{Cu}, \mathrm{Th}, \mathrm{Pb}$ and $\mathrm{Y}$. Enrichment factors for the elements listed above are variable, the maximum values (16-18) dealing with $\mathrm{Cr}$, Ni and $\mathrm{Rb}$.

The global chemistry of both lithologic groups is indicative of interaction between two magma types, alkaline silicatic and carbonatitic, as suggested by the presence of cumulitic (pyroxenitic and biotitic in composition) rocks. Particularly the higher $\mathrm{K}, \mathrm{Zr}$ and $\mathrm{Nb}$ contents of the mica-rich rocks, as compared to the carbonatites, could be related 

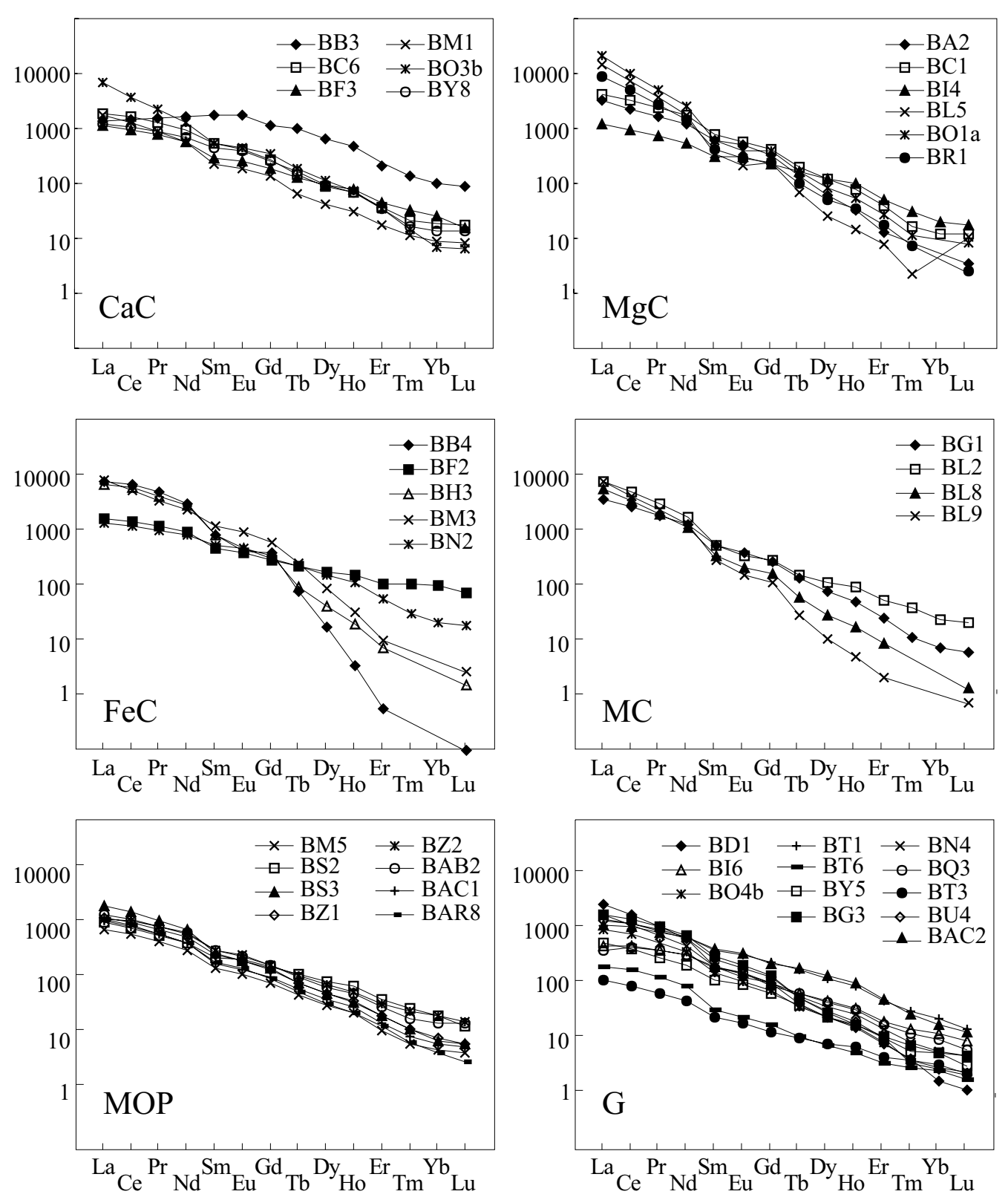

Fig. 9 - Chondrite normalized (Boynton 1984) REE patterns for carbonatites and mica-rich rocks from Araxá.

to metasomatic (glimmeritization) processes of the pyroxenites by fluids derived from the carbonatitic magma. Additionally, these fluids are also responsible for the fenitization of the country-rocks. Fig. 6 makes evident the $\mathrm{Zr}$ enrichment of $\mathrm{MC}$ and $\mathrm{G}$ rocks, these more affected by the potassic metasomatism, in comparison to the MOP ones. The relationship involving high $\mathrm{Nb}(\mathrm{Ta})$ and $\mathrm{Zr}$ concentrations and fenitization processes was also observed in xenoliths of fenitized granites occurring as inclusions in the Barra do Itapirapuã carbonatites (Ruberti 1998).

Chemical evidence (no significative relation 

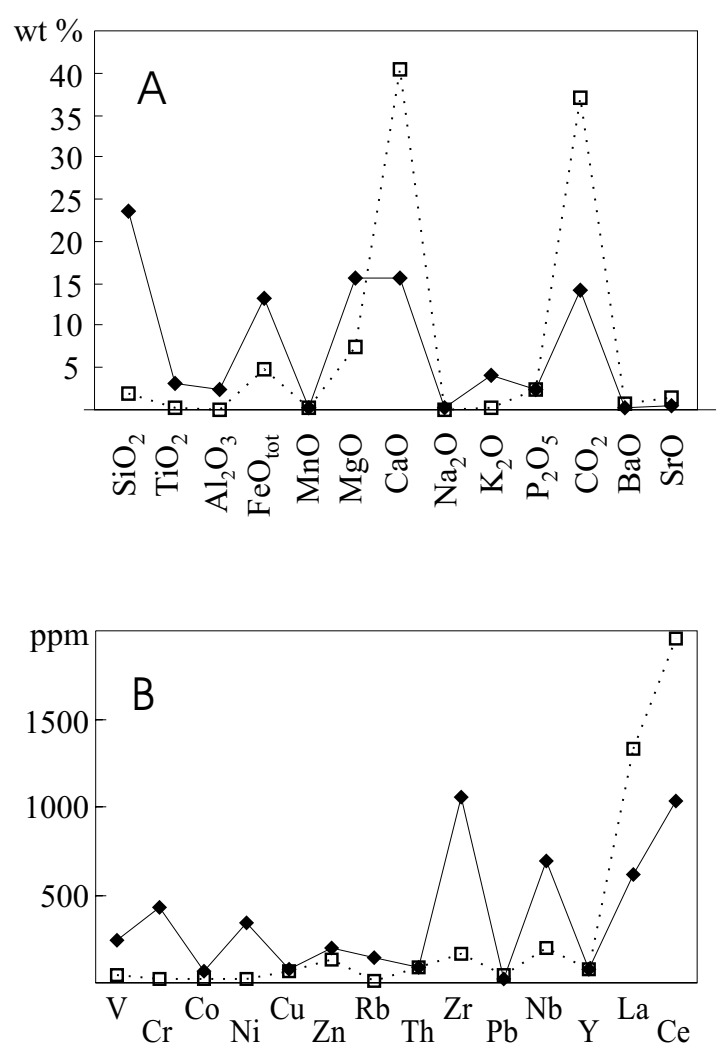

Fig. 10 -Average major (A) and trace element (B) compositions of carbonatites $(\mathrm{CaC}+\mathrm{MgC}+\mathrm{FeC}$, square $)$ and mica-rich rocks (G+MOP+MC, diamond) from Araxá.

between $\mathrm{P}_{2} \mathrm{O}_{5}$ and $\Sigma$ REE contents in Tables $\mathrm{V}$ and $\mathrm{VI}$ and absence of negative Eu anomaly in Fig. 9, this a common feature of apatites of other alkaline complexes, cf. Eby 1975, Hogarth 1989) may indicate that in Araxá rocks the REE concentrations are mainly associated to carbonate minerals instead of apatites. Carbonates can usually contain anomalous concentrations of REE (cf. Mariano 1989). Yet, in Araxá, they represent an important mineral phase and can be present in large amounts.

The similar REE patterns (Fig. 9) displayed by some carbonatites and mica-rich rocks samples are indicative of their formation from the same parental magma, which is thought to be derived by low partial melting of a metasomatized lithospheric mantle, mainly characterized by the presence of LREE- enriched phases (sphene?). As suggested by Le Bas and Handley (1979) on the basis of chemical analyses of apatites from western Kenya rocks, the same REE behaviour could also explain the carbonatites as formed by fractional crystallization of an ijolite magma and an evolution as a pair of immiscible, coniugate liquids (Le Bas 1989).

The high $\Sigma$ REE concentrations and the pronounced difference in LREE/HREE fractionation of some carbonatite samples could be related to direct or indirect enrichment processes regarding volatile transfer. It is well known from literature the different degree of mobility for the two REE groups, when associated to $\mathrm{H}_{2} \mathrm{O}$ and P-enriched fluids at mantle or crustal pressure, respectively. Also, it should be noted (cf. Hogarth 1989) that some minerals such as pyrochlore can be enriched in $\mathrm{La}, \mathrm{Ta}, \mathrm{Th}, \mathrm{Zr}$ and $\mathrm{U}$ and impoverished in HREE, $\mathrm{Ca}, \mathrm{F}$ and $\mathrm{Na}$ during weathering processes. Horning-Kjarsgaard (1998), studying the relationship between concentrations and REE patterns for bulk rock and minerals, emphasize the paralelism present in apatite, carbonate, unaltered pyrochore and bulk rock patterns. The authors also interpret some deviations as due to the presence of pyrochlore, a phase carrying a high REE content and exhibiting anomalous REE distribution.

It is also important to keep in mind the effects of solubilization and reprecipitation processes on the Araxá apatites. Analytical data point to presence of secondary apatite bearing low $\mathrm{Sr}$ and REE. The REE contents of the Araxá rocks are probably affected by hydrotermal and supergenic processes, as evidenced by the lack of correlation between rock compositions and $\Sigma$ REE values. An increase in $(\mathrm{La}+\mathrm{Ce})$ concentration through the evolutionary series calciocarbonatite - magnesio - carbonatite - ferrocarbonatite is postulated by Woolley and Kempe (1989) for carbonatite occurrences. However, as seen in Fig. 11, no relationship is shown by the investigated rocks. Pyroxenitic (MOP) and their metasomatic derived rocks $(\mathrm{G})$ are clearly less enriched in REE.

It is suggested that vapor phase has influenced the texture formation of the different types of car- 


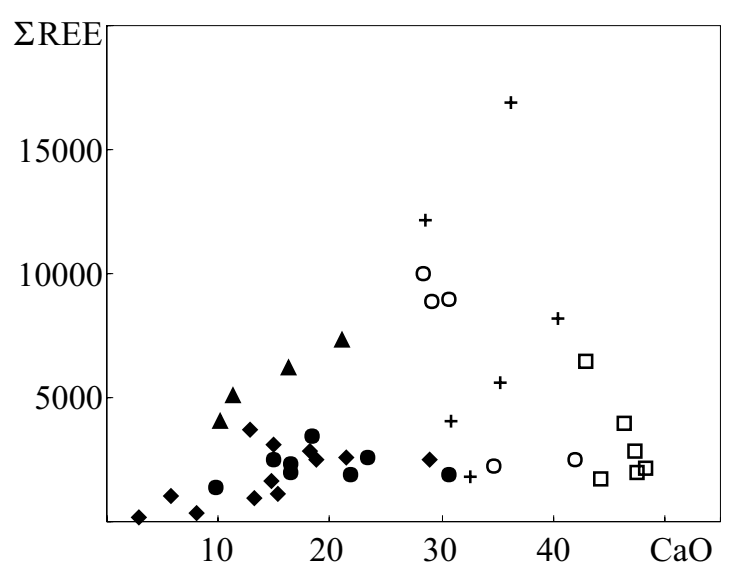

Fig. 11 - Composition of carbonatites and mica-rich rocks from Araxá plotted on the diagram $\Sigma$ REE vs. CaO. Symbols as in Fig. 6.

bonatites and is also responsible for the dominantly dolomitic mineralogy of these rocks, usually containing low $\mathrm{FeO}$ contents. The high $\mathrm{fO}_{2}$ is believed to favour the crystallization of oxides, such as magnetite, instead of iron-enriched carbonates (e.g. Fedolomite, ankerite). Thus, the fact that magnetite is widespread in all the rock-types and specially abundant in phoscorites, as well as the scarcity of ankerite, can be explained by the high $\mathrm{fO}_{2}$ conditions which have contributed to keep the system always impoverished in iron owing to the oxides precipitation.

The Araxá silicate rocks are basically represented by piroxenites exhibiting evidence of being metasomatized by potassic fluids of carbonatitic origin. Rocks corresponding to silicatic primitive liquids were not found. On the basis of cumulitic rocks an ijolitic composition could be admitted as parental magma.

As seen from the different boreholes, horizontal and vertical distribution of rock-types indicates that the glimmeritization processes have acted irregularly and variably in intensity. Data are suggesting the presence of horizons of cumulitic rocks mainly pyroxenitic in composition penetrated by small carbonatitic veins of different nature.
Petrological considerations on the Araxá carbonatites are constrained by the presently available data (the isotopic work is still in progress). For the Juquiá complex, Brazil, for instance, a carbonatitic origin related to liquid immiscibility from a parental basanitic magma is postulated by Beccaluva et al. (1992). However, it is possible to assume for many Brazilian alkaline-carbonatite complexes a derivation from different parental magmas subjected to variable melting degrees of heterogeneous mantle sources, as indicated by the distinct contents and patterns of REE of carbonatitic and associated silicatic rocks (Morbidelli et al. 1986, 1999, Barbieri et al. 1987, Gomes et al. 1987, 1990, Brotzu et al. 1989, 1994, Macciotta et al. 1990, Beccaluva et al. 1992, Traversa et al. 1996, Horning-Kjarsgaard 1998).

\section{ACKNOWLEDGMENTS}

The authors are grateful to Danilo Chiocchini, Enzo Pagana and Luca Bartolucci from the Department of Earth Sciences, University of Perugia, Italy, for technical assistance during X-ray diffraction, scanning electron microscopy, XRF and wet analyses

Thanks are also due to FAPESP (Proc. 97/ 01210-4) and M.U.R.S.T. (grants $40 \%$ and $60 \%$ University of Perugia and University of Rome "La Sapienza") for financial support.

\section{RESUMO}

O complexo de Araxá $\left(16 \mathrm{~km}^{2}\right)$ é constituído por carbonatitos na forma de um núcleo central e de complexa rede de diques concêntricos e radiais, além de pequenos veios; adicionalmente, ele contém rochas ricas em mica, foscoritos e lamprófiros. Fenitos também ocorrem e estão representados principalmente por quartzitos e xistos proterozóicos do Grupo Araxá.

O estudo petrográfico de 130 amostras de testemunhos de sondagem indica que o complexo reúne basicamente dois tipos litológicos, carbonatitos e rochas ricas em mica, e, subordinadamente, um terceiro de composição híbrida.

Carbonatitos apresentam composição química variável e têm magnésiocarbonatitos como o tipo mais abundante. Dolomita e calcita são os seus principais constituintes, mas outras fases carbonáticas, incluindo as pertencentes 
ao grupo dos carbonatos ricos em ETR, são também reconhecidas. Fosfatos e óxidos diversos caracterizam os acessórios mais comuns enquanto que os minerais silicáticos consistem de representantes dos grupos da olivina, clinopiroxênio, mica e anfibólio.

As rochas ricas em mica reúnem abundantes glimmeritos e escassos piroxenitos cumuláticos portadores de quantidades variáveis de flogopita, olivina e diopsídio. As rochas híbridas contêm principalmente flogopita e tetraferriflogopita, respectivamente, como fases cumulus e intercumulus; minerais carbonáticos podem também estar presentes.

Dados químicos indicam que os carbonatitos são fortemente enriquecidos em ETR e possuem teores mais baixos em $\mathrm{Nb}, \mathrm{Zr}, \mathrm{V}, \mathrm{Cr}$, Ni e $\mathrm{Rb}$ em relação às rochas mais ricas em mica. As concentrações mais altas em $\mathrm{K}, \mathrm{Nb}$ e $\mathrm{Zr}$ dessas últimas poderiam ser atribuídas a processos metassomáticos (glimeritização) que teriam afetado os piroxenitos.

O comportamento similar dos ETR nos carbonatitos e nas rochas ricas em mica parece sugestivo de que essas litologias estão relacionadas a um mesmo magma parental, possivelmente de composição ijolítica. O pronunciado fracionamento ETRL/ETRP e os elevados teores em ETR de algumas amostras de carbonatitos poderiam estar ligados a processos de natureza hidrotermal ou mesmo supergênicos.

Palavras-chave: rochas alcalinas, carbonatitos, geoquímica.

\section{REFERENCES}

Almeida FFM, Amaral G, Cordani UG \& Kawashita K. 1973. The Pre-Cambrian evolution of the South American cratonic margin south of the Amazon River. In: Nairn, EM \& Stheli, FG (Eds.) The ocean basins and margins. Plenum Publishing Co, New York, 1: 441-446

Almeida FFM, Hasui Y, Davino A \& Haralyi NLE. 1980. Informações geofísicas sobre o oeste mineiro e seu significado tectônico. An Acad Bras Ci 52: $50-60$.

Barbieri M, Beccaluva L, Brotzu P, Conte A, Garbarino C, Gomes CB, Loss EL, Macciotta G, Morbidelli L, Scheibe LF, Tamura RM \& Traversa G. 1987. Petrological and geochemical studies of alkaline rocks from continental Brazil. 1. The phonolite suite from Piratini, RS. Geochim Brasil 1: 109-138.

Beccaluva L, Born H, Brotzu P, Coltorti M, Conte A, Garbarino C, Gomes CB, Macciotta G, Morbidelli L, Ruberti E, Siena F \& Traversa G. 1992. Fractional crystallization and liquid immiscibility processes in the alkaline-carbonatite complex of Juquiá (São Paulo, Brazil). J Petrol 33: 1371-1404.

Boynton WV. 1984. Cosmochemistry of the rare earth elements: meteorite studies. In: Henderson P (Ed.) Rare earth element geochemistry. Elsevier, New York, p.63-107.

Brotzu P, Beccaluva L, Conte A, Fonseca M, Garbarino C, Gomes CB, Leong R, Macciotta G, Mansur RL, Melluso L, Morbidelli L, Ruberti E, Sigolo JB, Traversa G \& Valença JB. 1989. Petrological and geochemical studies of alkaline rocks from continental Brazil. 8. The syenitic intrusion of Morro Redondo intrusive complex, State of Rio de Janeiro. Geochim Brasil 3: 63-80.

Brotzu P, Barbieri M, Beccaluva L, Born H, Coltorti M, Garbarino C, Gomes CB, Macciotta G, Melluso L, Morbidelli L, Ruberti E \& Traversa G. 1994. Petrology and geochemistry of the Passa Quatro alkaline complex, southeastern Brazil. J South Amer Earth Sci 6: 237-252.

Deer WA, Howie RA \& Zussman J. 1964. Rockforming minerals. Vol. 5, Longmans.

EBy GN. 1975. Abundance and distribution of the rare earth elements and yttrium in the rocks and minerals of the Oka carbonatite complex, Quebec. Geochim Cosmochim Acta 39: 597-620.

Erd RC, Czamanske GK \& Meyer CE. 1983. Taeniolite an uncommon lithium-mica from Coyote Peak County, California. The Mineralogical Record 14: $39-40$.

Foster MD. 1960. Interpretation of the composition of lithium micas. U.S. Geol Surv, Prof. Paper 354 E, 115-147.

Gibson AS, Thompson RN, LeONARdos OH, Dickin AP \& Mitchell JB. 1995. The Late Cretaceous impact of the trindade mantle plume; evidence from large- 
volume, mafic, potassic magmatism in SE Brazil. $J$ Petrol 36: 189-229.

Gomes CB, Barbieri M, Beccaluva L, Brotzu P, Conte A, Garbarino C, Macciotta G, Melluso L, Morbidelli L, Ruberti E, Scheibe LF, Tamura RM \& Traversa G. 1987. Petrological and geochemical studies of alkaline rocks from continental Brazil. 2. The Tunas massif, State of Paraná. Geochim Brasil 1: 201-234.

Gomes CB, Ruberti E \& Morbidelli L. 1990. Carbonatite complexes from Brazil: A review. J South Amer Earth Sci 3: 51-63.

Grossi-SAD JH \& ToRres N. 1976. Geology and mineral resources of the Barreiro Complex, Araxá, Brazil. In: Simpósio Internacional de Carbonatitos. Poços de Caldas, Brasil 1976.

Hasui Y \& CoRDANI UG. 1968. Idades potássio-argônio de rochas eruptivas mesozóicas do Oeste Mineiro e Sul de Goiás. In: XXII Congresso Brasileiro de Geologia. Belo Horizonte p. 139-143.

Hasui Y, Sadowski GR, Suguio K \& Fuck GF. 1975. The phanerozoic tectonic evolution of the western Minas Gerais State. An Acad Bras Ci 47: 431-438.

HEINRICH EW. 1980. The geology of carbonatites. Robert E. Krieger Publishing Company, New York, 585 p.

Hogarth DD. 1977. Classification and nomenclature of the pyrochlore group. Amer Mineral 62: 403-410.

Hogarth DD. 1989. Pyrochlore, apatite and amphibole: distinctive minerals in carbonatite. In: Bell, K. (Ed.) Carbonatites: genesis and evolution. Unwin Hyman Ltd, London p. 105-148.

HoRNIG-KJARSGAARD I. 1998. Rare earth elements in sovitic carbonatites and their mineral phases. J Petrol 39: $2105-2121$.

Issa Filho A, Lima dos Santos PRA \& Souza OM. 1984. Aspects of the geology of the Barreiro Carbonatitic Complex, Araxá, MG, Brazil. In: Carbonatitic complexes of Brazil: geology. Companhia Brasileira de Metalurgia e Mineração, São Paulo, p. 19-44.

KaruP-MøLler S. 1986. Nenadkevikite from the Ilimaussaq intrusion in South Greenland. N Jahr Min- eral Monatsh 2: 49-58.

Kasputin YL. 1980. Mineralogy of carbonatites. Amerind Publishing Co. Pvt. Ltd., New Delhi 256p.

Keller J \& Schleicher H. 1990. Post-conference excursion 2B: volcanism and petrology of the Kaiserstuhl. IAVCEI, International Volcanological Congress, Mainz (FRG).

Кномуакоv AP. 1995. Mineralogy of hyperagpaitic alkaline rocks. Clarendon Press, Oxford p. 223.

LE BAS MJ. 1989. Diversification of carbonatite. In: Bell, K. (Ed.) Carbonatites: genesis and evolution. Unwin Hyman Ltd. London p. 428-447.

Le Bas MJ \& HandLey C. 1979. Variation in apatite composition in ijolitic and carbonatitic igneous rocks. Nature 279: 54-56.

Leake BE, Wooley AR, Arps CES, Birch WD, Gilbert MC, Grice JD, Hawthorne FC, Kato A, Kisch HJ, Krivovichev VG, Linthout K, Laird J, Mandarino J, Maresch WV, Nickel EH, Rock NMS, Schumacher JC, Smith DC, StephenSON NCN, Ungaretti L, Whittaker EJW \& YouzHI G. 1997. Nomenclature of amphiboles. Report of the Subcommittee on Amphiboles of the International Mineralogical Association Commission on New Minerals and Mineral Names. Eur J Mineral 9: 623-651.

Macciotta G, Almeida A, Barbieri M, Beccaluva L, Brotzu P, Coltorti M, Conte A, Garbarino C, Gomes CB, Morbidelli L, Ruberti E, Siena F \& Traversa G. 1990. Petrology of the tephritephonolite suite and cognate xenoliths of the Fortaleza district (Ceará, Brazil). Eur J Mineral 2: 687-709.

Mariano AN. 1989. Nature of economic mineralization in carbonatites and related rocks. In: Bell, K. (Ed.) Carbonatites: genesis and evolution. Unwin Hyman Ltd. London p. 149-176.

Milton C, Ingram BL \& Blade LV. 1961. Kimzeyite, a zirconium garnet from Magnet Cove, Arkansas. Amer Mineral 46: 533-548.

Morbidelli L, Beccaluva L, Brotzu P, Conte A, Garbarino C, Gomes CB, Macciotta G, Ruberti E, Scheibe LF \& Traversa G. 1986. Petrological and geochemical studies of alkaline rocks from con- 
tinental Brazil. 3. Fenitization of jacupirangite by carbonatite magmas in the Jacupiranga complex, SP. Per Mineral 55: 261-295.

Morbidelli L, Gomes C, Beccaluva L, Brotzu P, Conte AM, Ruberti E \& Traversa G. 1995. Mineralogical, petrological and geochemical aspects of alkaline-carbonatite associations from Brazil. EarthSci Ver 39: 135-168.

Morbidelli L, Gomes CB, Beccaluva L, Brotzu P, Garbarino C, Riffel BF, Ruberti E \& Traversa G. 1997. Parental magma characterization of Salitre cumulate rocks (Alto Paranaíba Alkaline Province, Brazil) as inferred from mineralogical, petrographic, and geochemical data. Int Geol Ver 39: 723-743.

Morbidelli L, Gomes CB, Brotzu P, D'Acquarica S, Garbarino CP, Ruberti E \&. Traversa G. 1999. The Pariquera Açu K-alkaline complex and southern Brazil lithospheric mantle source characteristics. $J$ Asian Earth Sci 18: 129-150.

Papike JJ, Cameron K \& Baldwin K. 1974. Amphiboles and pyroxenes: characterization of other than quadrilateral components and estimates of ferric iron from microprobe data. Bull Geol Amer Soc 6: 10531054.

PIRES RM. 1986. The southern limits of the São Francisco craton. An Acad Bras Ci 58: 139-145.

Platt GR \& Woolley AR. 1990. The carbonatites and fenites of Chipman Lake, Ontario. Canad Mineral 28: $241-250$.
RUBerti E. 1998. Petrologia e geoquímica das suítes carbonatíticas de Mato Preto (PR) e da Barra de Itapirapuã (PR-SP). Tese de Livre-Docência, Universidade de São Paulo, 211p.

SONOKI IK \& GARDA GM. 1988. Idades K/Ar de rochas alcalinas do Brasil Meridional e Paraguai Oriental: compilação e adaptação às novas constantes de decaimento. Bol. IG-USP, Sér Cient 19: 63-68.

Speer JA \& Hensley-Dunn ML. 1976. Strontianite composition and physical properties. Amer Mineral 61: 1001-1004

Traversa G, Barbieri M, Beccaluva L, Coltorti M, Conte AM, Garbarino C, Gomes CB, Macciotta G, Morbidelli L, Ronca S \& Scheibe LF. 1996. Mantle sources and differentiation of alkaline magmatic suite of Lages, Santa Catarina, Brazil. Eur J Mineral 8: 193-208.

UlbRICH HHGJ \& Gomes CB. 1981. Alkaline rocks from continental Brazil. Earth Sci Rev 17: 135-154.

Woolley AR. 1982. A discussion of carbonatite evolution and nomenclature, and the generation of sodic and potassic fenites. Mineral Mag 46: 13-17.

Woolley AR \& Kempe DRC. 1989. Carbonatites: nomenclature, average chemical compositions, and element distribution. In: Bell, K. (Ed.) Carbonatites: genesis and evolution. Unwin Hyman Ltd. London p.1-14. 